\title{
ॠUSGS
}

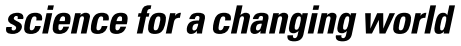

Prepared in cooperation with the Little Rock District, U.S. Army Corps of Engineers, Little Rock, Arkansas

\section{Lithology, Hydrologic Characteristics, and Water Quality of the Arkansas River Valley Alluvial Aquifer in the Vicinity of Van Buren, Arkansas}

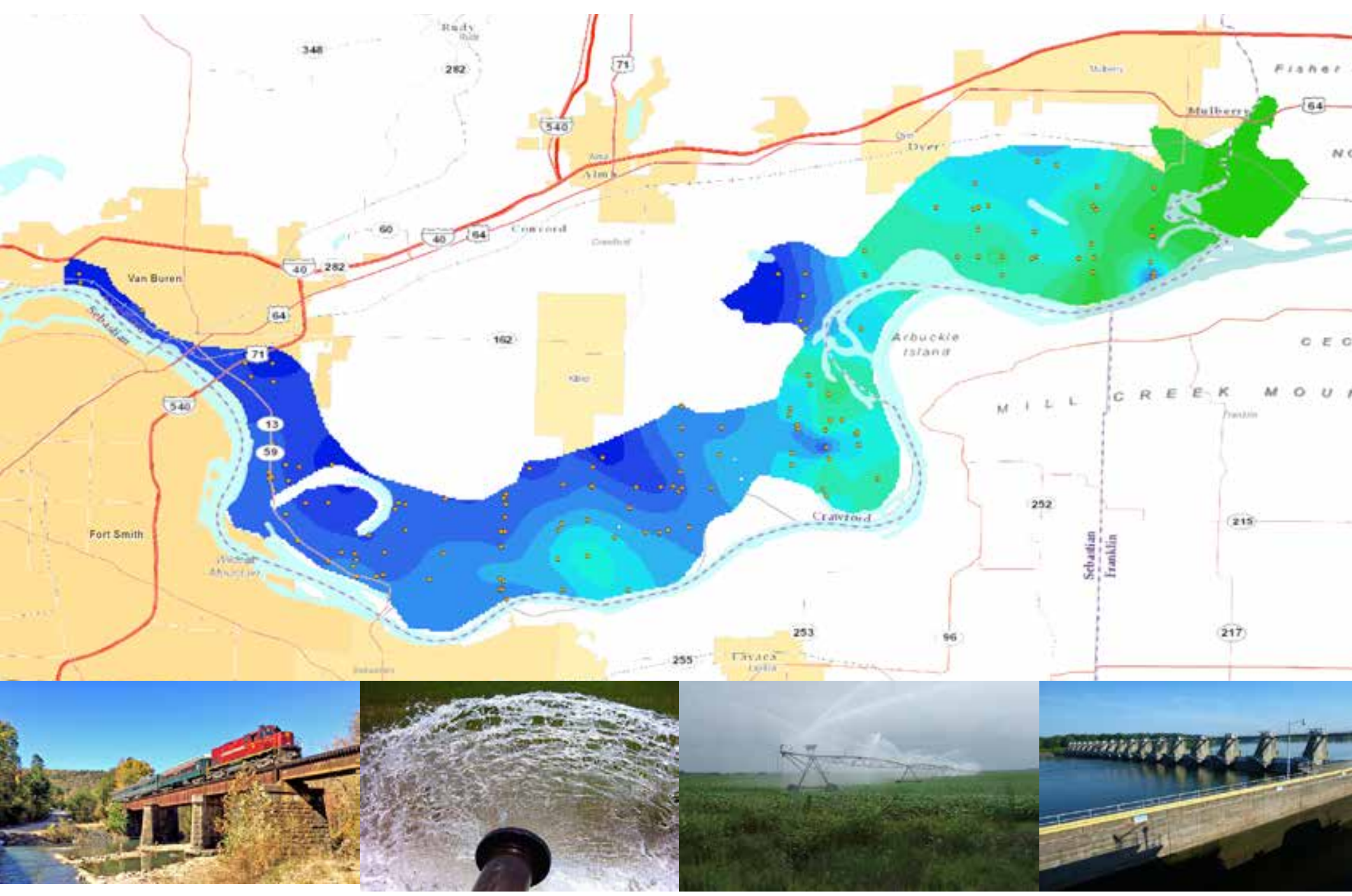

Scientific Investigations Report 2015-5044

U.S. Department of the Interior

U.S. Geological Survey 


\section{Front cover photographs (left to right):}

The A\&M Railroad excursion train crossing a bridge in the vicinity of Van Buren, Arkansas (photograph by Brock Girard, Williams/Crawford \& Associates).

Water well used for irrigation in the vicinity of Van Buren, Arkansas (U.S. Geological Survey photograph by Ralf Montanus).

Pivot irrigation of farmland in the Arkansas River Valley in the vicinity of Van Buren, Arkansas (U.S.

Geological Survey photograph by Ralf Montanus).

Lock and dam system on the Arkansas River (U.S. Geological Survey photograph by Drew A.

Westerman). 


\section{Lithology, Hydrologic Characteristics, and Water Quality of the Arkansas River Valley Alluvial Aquifer in the Vicinity of Van Buren, Arkansas}

By Timothy M. Kresse, Drew A. Westerman, and Rheannon M. Hart

Prepared in cooperation with the Little Rock District, U.S. Army Corps of

Engineers, Little Rock, Arkansas

Scientific Investigations Report 2015-5044 


\title{
U.S. Department of the Interior SALLY JEWELL, Secretary
}

\section{U.S. Geological Survey \\ Suzette M. Kimball, Acting Director}

\author{
U.S. Geological Survey, Reston, Virginia: 2015
}

For more information on the USGS - the Federal source for science about the Earth, its natural and living resources, natural hazards, and the environment—visit http://www.usgs.gov or call 1-888-ASK-USGS.

For an overview of USGS information products, including maps, imagery, and publications, visit http://www.usgs.gov/pubprod/.

Any use of trade, firm, or product names is for descriptive purposes only and does not imply endorsement by the U.S. Government.

Although this information product, for the most part, is in the public domain, it also may contain copyrighted materials as noted in the text. Permission to reproduce copyrighted items must be secured from the copyright owner.

Suggested citation:

Kresse, T.M., Westerman, D.A., and Hart, R.M., 2015, Lithology, hydrologic characteristics, and water quality of the Arkansas River Valley alluvial aquifer in the vicinity of Van Buren, Arkansas: U.S. Geological Survey Scientific Investigations Report 2015-5044, 26 p., http://dx.doi.org/10.3133/sir20155044.

ISSN 2328-0328 (online) 


\section{Contents}

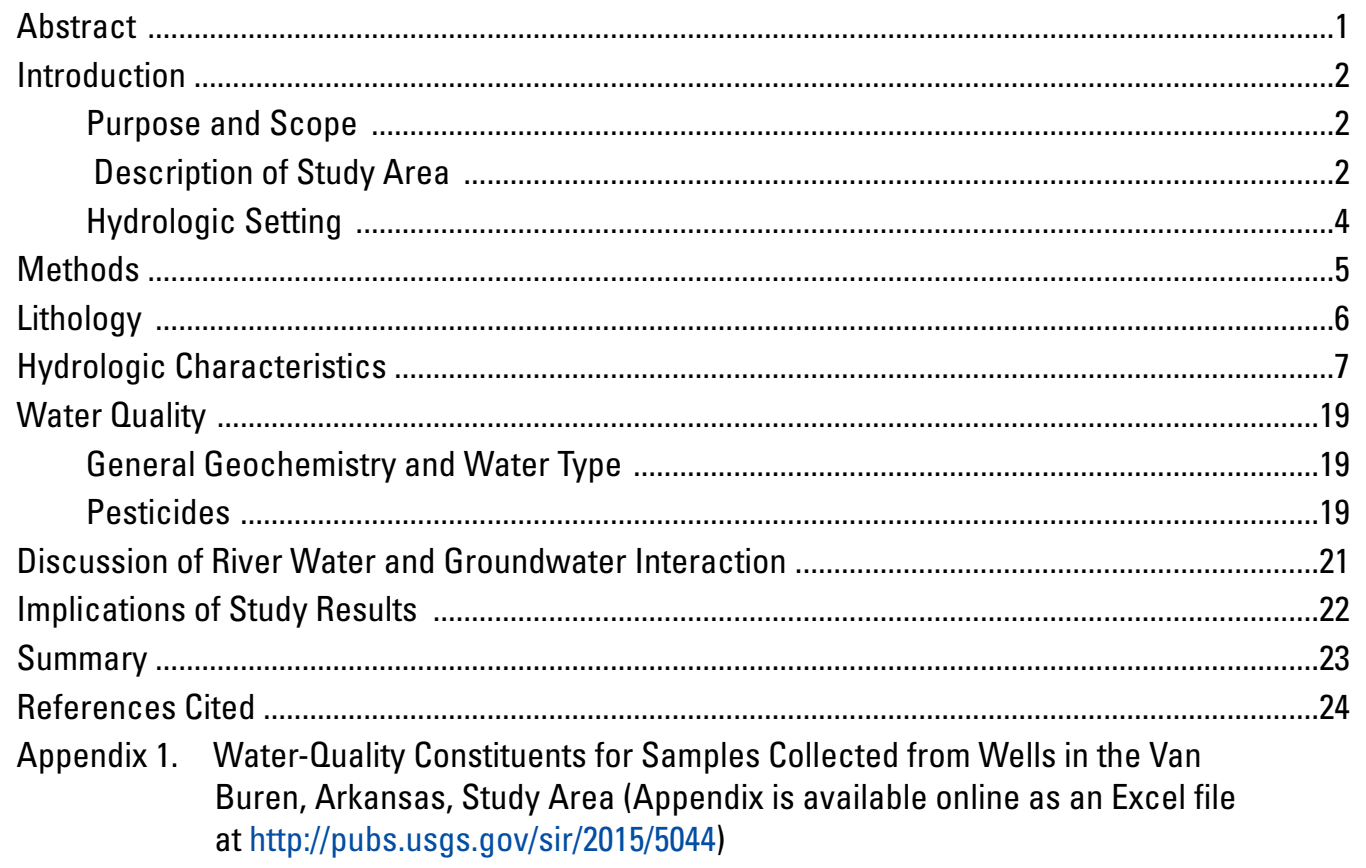

\section{Figures}

1. Map showing location of historic wells, including those used to construct hydrographs, and water-quality sampling sites near the Van Buren study area, Arkansas

2. Map showing sand percentage derived from drillers' logs overlain onto an orthophotograph near the Van Buren study area, Arkansas ...............................................8

3. Hydrographs of groundwater level and cumulative departure from mean monthly and mean annual precipitation in the Van Buren study area, Arkansas..

4. Graph showing groundwater level and precipitation data for real-time site in the Van Buren study area, Arkansas...

5. Hydrographs of groundwater level, river stage, and cumulative departure from mean monthly precipitation for wells upstream from the James W. Trimble Lock and Dam 13 in the Van Buren study area, Arkansas

6. Graph showing arsenic and iron concentrations in groundwater samples from wells located in the Van Buren study area, Arkansas. 


\section{Conversion Factors}

Inch/Pound to International System of Units

\begin{tabular}{lcl}
\hline \multicolumn{1}{c}{ Multiply } & By & \multicolumn{1}{c}{ To obtain } \\
\hline inch (in.) & Length & \\
inch (in.) & 2.54 & centimeter $(\mathrm{cm})$ \\
foot (ft) & 25.4 & millimeter $(\mathrm{mm})$ \\
mi (mi) & 0.3048 & meter $(\mathrm{m})$ \\
& 1.609 & kilometer $(\mathrm{km})$ \\
\hline square mi $\left(\mathrm{mi}^{2}\right)$ & Area & \\
square mi (mi $\left.{ }^{2}\right)$ & 259.0 & hectare $(\mathrm{ha})$ \\
& 2.590 & square kilometer $\left(\mathrm{km}{ }^{2}\right)$ \\
\hline gallon per minute (gal/min) & Flow rate & \\
million gallons per day (Mgal/d) & 0.06309 & liter per second $(\mathrm{L} / \mathrm{s})$ \\
inch per year (in/yr) & 0.04381 & cubic meter per second $\left(\mathrm{m}^{3} / \mathrm{s}\right)$ \\
\hline
\end{tabular}

\section{Datum}

Vertical coordinate information is referenced to the National Geodetic Vertical Datum of 1929 (NGVD 29)

Horizontal coordinate information is referenced to the North American Datum of 1983 (NAD 83)

\section{Supplemental Information}

Altitude, as used in this report, refers to distance above the vertical datum.

Concentrations of chemical constituents in water are given either in milligrams per liter (mg/L) or micrograms per liter ( $\mu \mathrm{g} / \mathrm{L})$.

\section{Abbreviations}
AGC Arkansas Geological Commission
$\mathrm{R}^{2} \quad$ Coefficient of determination
USCE U.S. Army Corps of Engineers
USGS U.S. Geological Survey 


\title{
Lithology, Hydrologic Characteristics, and Water Quality of the Arkansas River Valley Alluvial Aquifer in the Vicinity of Van Buren, Arkansas
}

\author{
By Timothy M. Kresse, Drew A. Westerman, and Rheannon M. Hart
}

\section{Abstract}

A study to assess the potential of the Arkansas River Valley alluvial aquifer in the vicinity of Van Buren, Arkansas, as a viable source of public-supply water was conducted by the U.S. Geological Survey in cooperation with the Little Rock, District, U.S. Army Corps of Engineers. An important study component was to identify possible changes in hydrologic conditions following installation of James W. Trimble Lock and Dam 13 (December 1969) on the Arkansas River near the study area. Data were gathered for the study in regard to the lithology, hydrologic characteristics, and water quality of the aquifer. Lithologic information was obtained from drillers' logs of wells drilled from 1957 through 1959. Water-quality samples were collected from 10 irrigation wells and analyzed for inorganic constituents and pesticides. To evaluate the potential viability of the alluvial aquifer in the Van Buren area, these data were compared to similar stratigraphic, lithologic, and groundwater-quality data from the Arkansas River Valley alluvial aquifer at Dardanelle, Ark., where the aquifer provides a proven, productive, sole-source of public-supply water.

Drillers' logs for 59 wells in the Van Buren study area revealed well depths ranging from 25 to 52 feet (ft), with a mean depth of $42 \mathrm{ft}$. The thickness of the lower sand/gravel interval serving as the water-producing zone ranged from 5 to $47 \mathrm{ft}$, with a mean thickness of $29 \mathrm{ft}$. The presence of gravel was noted in only 4 of 59 well logs available for review from the study area.

Percent sand was calculated from well logs in the study area, and these sand percentages were overlain onto an orthophotograph map to examine the areal distribution of sand percentage in relation to geomorphologic features of the flood plain in the study area. The logs denoting the greatest percent sand tend to occur in areas near to the river and on the concave (point bar) side of abandoned channels, while the lower percent sand tends to occur on the convex (channel fill and backswamp deposits) side of the abandoned channels.

Comparison of hydrographs from water levels collected between 1957 and 1972 to cumulative departure from mean monthly and mean annual precipitation showed overall good fit and explained the long-term decreasing water levels from the earliest period of record through October 1967, followed by a sharp rise in water levels concurrent with rises in cumulative departure from mean monthly and mean annual precipitation. Hydrographs for four wells ranging from 0.8 to 4.5 miles upstream from the dam and potentially affected by rising river stage were compared to graphs of river stage and cumulative departure from mean monthly precipitation. Water levels for these wells showed minimal discernible effect by rising river stage following dam completion. Periods of increased precipitation compared closely to increases in water level for all hydrographs, regardless of river stage, and periods of no precipitation resulted in declining water levels, although river stage continued to slowly rise during these same periods.

The Arkansas River has greater salinity than local groundwater, providing a quantitative tracer for any groundwater recharge originating from the river. Comparison of predam and postdam groundwater-chloride concentrations showed no increase in chloride concentrations after dam installation, which is consistent with hydrologic data. These data suggest that the dominant source of groundwater recharge in the Arkansas River Valley alluvial aquifer is infiltration of precipitation through proximal, coarse channel deposits, with minimal influx of river water.

Groundwater-quality data collected from 10 wells in the study area indicated a calcium-bicarbonate water type. No primary drinking-water standards were exceeded for any constituents, and iron and manganese were the only constituents exceeding secondary drinking-water regulations. Six of the 10 well-water samples were analyzed for the presence of pesticides, as row-crop agriculture is the dominant land use in the study area. Six herbicide compounds and one herbicide metabolite were detected at concentrations substantially below those of the Federal primary drinking-water standards and health advisories.

The hydrologic and geochemical data gathered for this study provide a qualitative assessment of the potential of the Arkansas River Valley alluvial aquifer as a source of public water supply in the Van Buren area. Results indicate minimal influx of water from the Arkansas River, and recharge to the aquifer appears to be dominantly by infiltration of precipitation through overlying alluvium. If vertical wells are used as a source of public water supply, then several wells will have to be used in combination at relatively low pumping rates and 
placed in areas with a greater percent sand. Use of a horizontal well configuration near the river to increase production may depend on infiltration of river water to supplement water removed from storage, especially where areas of lower permeability sediments might be encountered within the surrounding alluvium. If a poor hydraulic connection exists between the river and the alluvium, as indicated by this study, then production will depend on ample precipitation and recharge throughout the year and groundwater storage sufficient to prevent declining water levels where pumping rates exceed recharge.

\section{Introduction}

A continuous and reliable supply of water available in adequate quantities and of a quality sufficient to meet the increasing demands of drinking, industrial, commercial, energy, and agricultural uses is a major and growing concern throughout the United States, even in areas once considered rich in water. Although Arkansas receives an average of approximately 50 inches per year (in/yr) of rainfall (Pugh and Westerman, 2014), the uneven seasonal and areal distribution of this rainfall presents numerous problems from a supply perspective. Demand from various users can result in seasonal and annual allocation problems for any one use. The River Valley Regional Water District is one of several organizations in Arkansas involved in ensuring sustainability of water resources and has been investigating additional sources of public water supply in the area of Van Buren, Ark., and surrounding communities.

The U.S. Army Corps of Engineers (USCE) worked with the River Valley Regional Water District to identify reliable and high-quality sources of drinking water for Van Buren and surrounding communities. The U.S. Geological Survey (USGS) in cooperation with the USCE conducted a study to qualitatively assess groundwater as a viable water supply. Use of groundwater in the alluvial deposits along the Arkansas River Valley, hereinafter referred to as the Arkansas River Valley alluvial aquifer, was one of several options assessed by the USCE. Prior to this study, few data were available to assess production capacity or groundwater quality within the Arkansas River Valley alluvial aquifer in the Van Buren area. The cities of Atkins, Morrilton, Ozark, and Dardanelle in Arkansas previously used the Arkansas River Valley alluvial aquifer as a source of public water supply (Bedinger and others, 1963). Currently (2014), Dardanelle and Maumelle are the only municipalities using the aquifer as a public water supply.

The main activities associated with this study were to describe the stratigraphy using available drillers' logs, with an emphasis on assessing the thickness of water-producing sand and gravel layers; to create hydrographs from groundwater-level data and graphs of precipitation and river stage; to assess the prevailing hydrologic conditions prior to and after the completion of James W. Trimble Lock and Dam 13 near Van Buren (hereinafter referred to as Trimble Lock and Dam) in December 1969; to collect groundwater samples from selected irrigation wells for water-quality analysis and compare those data to Federal drinking-water standards and regulations; and to compare all data collected from the study area to stratigraphic, lithologic, and groundwater-quality data from a location where the Arkansas River Valley alluvial aquifer has been proven as a viable, long-term public-supply water source for the city of Dardanelle, Ark. Field activities for this study included identification of existing production wells, measurement of groundwater levels, and collection of water-quality samples.

\section{Purpose and Scope}

The purpose of this report is to describe the lithology, hydrologic characteristics, and geochemistry of the Arkansas River Valley alluvial aquifer near Van Buren, Ark., and evaluate the potential viability of the aquifer as a drinking-water supply for Van Buren and surrounding communities. This report presents field and water-quality data collected for this study and historical data used to evaluate production-zone thickness, stratigraphy, and water-table response to precipitation. Historic data collected between 1957 and 1959 by the USCE, the USGS, and the Arkansas Geological Commission (now the Arkansas Geological Survey) to assess potential flooding from planned installation of dams along the Arkansas River were used to describe the hydrology and groundwater geochemistry in the vicinity of Van Buren. Because data compiled for this report were from the Arkansas River Valley alluvial aquifer in the vicinity of Van Buren, study results are preliminary in nature and may not be transferable to other parts of the Arkansas River Valley alluvial aquifer.

A review of available data was made with the intent of identifying major recharge sources in the study area because use of groundwater in the study area depends on adequate recharge to offset water removed from storage,. Results of this activity were based on interpretation of existing data and thus cannot be used to predict hydrologic conditions that may change with the initiation of large-scale pumping for public supply.

\section{Description of Study Area}

The study area is defined by the extent of the alluvial deposits located in northwestern Arkansas in an area generally bounded to the west, north, and east by the cities of Van Buren, Kibler, Dyer, and Mulberry, and the Arkansas River to the south (fig. 1). The area is characterized by generally flat-lying topography developed on flood-plain deposits of the Arkansas River. The width of the alluvial sediments in the study area extends northward from the Arkansas River an average distance of approximately 2 miles (mi), and the total area of the alluvium in the study area is approximately 20 square miles $\left(\mathrm{mi}^{2}\right)$. The flat-lying terrain of the alluvial flood plain in the study area ranges from an altitude of 375 feet (ft) above National Geodetic Vertical Datum of 1929 (NGVD 29) to $409 \mathrm{ft}$ above NGVD 29. 


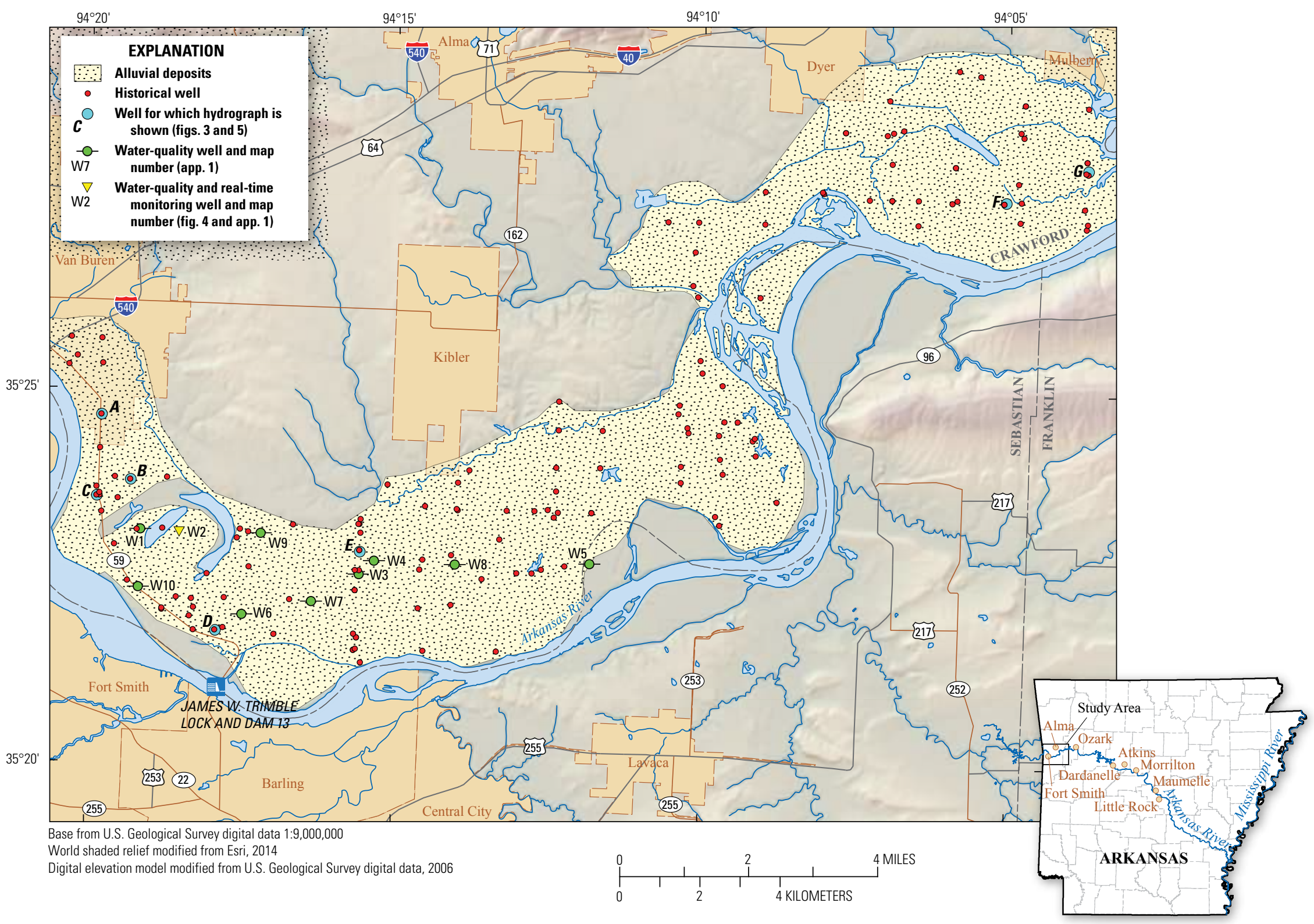

Figure 1. Location of historic wells, including those used to construct hydrographs, and water-quality sampling sites near the Van Buren study area, Arkansas. 
Lithology, Hydrologic Characteristics, and Water Quality of the Arkansas River Valley Alluvial Aquifer

Situated on rich, flood-plain deposits from the Arkansas River, the dominant land use in the study area is row-crop agriculture. Soybeans accounted for approximately 80 percent of the cropland in 2011, with corn and wheat and other minor crops accounting for the remaining cropland, depending on market conditions. In the past, contract vegetable farming, including spinach, kale, collards, southern peas, and other crops accounted for a large part of row-crop agriculture, but these crops have declined as a substantial part of the acreage; however, a small amount of vegetable farming for local canneries still occurs in the study area (Larry Martin, Yell County, Arkansas Cooperative Extension Service, oral commun., 2011). Dry-land farming is common throughout the area, and irrigation occurs only where water-producing sands and gravels of sufficient thickness occur within the Arkansas River Valley alluvial deposits (see section titled "Lithology").

\section{Hydrologic Setting}

Groundwater is one of the most important resources in Arkansas and accounts for 66 percent of the total combined water use in the State (Holland, 2007). Aquifers composed of alluvial sands and gravels are a productive source of groundwater supply in Arkansas and account for most of the groundwater use. The most productive alluvial aquifer system is the Mississippi River Valley alluvial aquifer in eastern Arkansas, which yields an average of approximately 1,400-1,600 gallons per minute (gal/min) (Klein and others, 1950; Bedinger and Reed, 1961) and accounts for approximately 98 percent of groundwater use in Arkansas (Holland, 2007). Although the Arkansas River Valley alluvial deposits are thinner and less productive than the Mississippi River Valley alluvial deposits, the Arkansas River Valley alluvial aquifer serves as an important local source of irrigation and public-supply water.

Substantially less groundwater is used in western Arkansas than the remainder of the State as a direct result of lower yields from shallow (less than $500 \mathrm{ft}$ ) aquifers dominantly composed of fractured clastic bedrock with wells that typically yield less than $10 \mathrm{gal} / \mathrm{min}$ (Cordova, 1964). The Roubidoux Formation and Gunter Sandstone Member of the Gasconade Formation serve as an important and high-yield (as much as $600 \mathrm{gal} / \mathrm{min}$ ) source of public-supply water in northwestern Arkansas, but this aquifer system becomes increasingly more saline near the Arkansas River Valley (Prior and others, 1999). Therefore, the Arkansas River Valley alluvial aquifer is one of the few groundwater sources in the western part of the State having good-quality water with sufficient yields for irrigation, public supply, and other large-demand users. Bedinger and others (1963) reported that yields from wells completed in the Arkansas River Valley alluvial aquifer range from 300 to $700 \mathrm{gal} / \mathrm{min}$. Although the alluvium along the $200 \mathrm{mi}$ of the Arkansas River from Fort Smith to Little Rock is restricted in width — generally ranging from 1 to $3 \mathrm{mi}$ wide - the high yields from this aquifer system make it a desirable source of irrigation and public-supply water for communities in close proximity to the Arkansas River.

In the city of Dardanelle, Ark., the Arkansas River Valley alluvial aquifer is a proven, long-term source for public-supply water. The city extracted water from 12 wells completed in the Arkansas River Valley alluvial aquifer with average yields of approximately $200 \mathrm{gal} / \mathrm{min}$ through 2011 . Dardanelle recently completed the construction of a horizontal interceptor well system with five laterals ranging from 150 to $250 \mathrm{ft}$ in length in the Arkansas River Valley alluvial aquifer approximately $300 \mathrm{ft}$ from the river that produced greater than 2.5 million gallons per day (Mgal/d) in 2013. The horizontal interceptor well system replaced the 12 vertical production wells in January 2011 (Bill Smith, Dardanelle Water Works, oral commun., 2013). Kline and others (2006) and Kresse and others (2006) investigated the hydrogeology and geochemistry of the Arkansas River Valley alluvial aquifer in Dardanelle to describe the hydrology, define the flow directions, and document the water-quality effects of river water infiltration into the well field. Therefore, abundant hydrologic and water-quality data are available for the Arkansas River Valley alluvial aquifer in this area.

Data pertaining to hydraulic characteristics are critical for assessing any aquifer as a reliable source of public-supply water. Although Bedinger and others (1963) reported yields as much as $700 \mathrm{gal} / \mathrm{min}$ for wells completed in the Arkansas River Valley alluvial aquifer from Fort Smith to Little Rock, their report listed yields in individual wells as low as $75 \mathrm{gal} /$ min in some locations - no yield data were available in the study area. In addition to Dardanelle and Maumelle, Ark., which currently (2014) pump water from the Arkansas River Valley alluvial aquifer, the cities of Atkins, Morrilton, and Ozark were listed in Bedinger and others (1963) as systems in Arkansas previously using the Arkansas River Valley alluvial aquifer as their sole source of public-supply water. For various reasons, these cities eventually switched to surface-water sources, which indicates possible quantity or quality problems for select areas of the Arkansas River Valley alluvial aquifer.

An understanding of sources and amount of aquifer recharge is an important criterion for assessing groundwater as a long-term water supply. While no study has been conducted to confidently quantify actual recharge rates across the aquifer, calibrated Mississippi River Valley alluvial aquifer groundwater models have applied recharge rates from 0.8 to $2.6 \mathrm{in} / \mathrm{yr}$ (about 1.5 to 5 percent of total precipitation) to simulate recharge from precipitation (Mahon and Poynter, 1993; Ackerman, 1996; Arthur, 2001; Stanton and Clark, 2003). These models, however, integrate locally low and high values of recharge and represent average recharge rates across large basin-scale areas of the Mississippi River Valley alluvial aquifer. Kresse and Clark (2008) applied a chloride mass balance method using chloride concentrations in precipitation and groundwater to show a range of recharge values from lows near $0.07 \mathrm{in} / \mathrm{yr}$ to $7.8 \mathrm{in} / \mathrm{yr}$ in areas of Mississippi River Valley backswamp and channel deposits, respectively, south of 
the Arkansas River in eastern Arkansas. Bedinger and others (1963) calculated a recharge value of $10 \mathrm{in} / \mathrm{yr}$ through channel deposits along the Arkansas River in western Arkansas, which generally corresponds to the higher recharge value of $7.8 \mathrm{in} / \mathrm{yr}$ for channel deposits from Kresse and Clark (2008).

Prior to the installation of the lock and dam system beginning in 1967, the Arkansas River acted as a drain for groundwater flow throughout most years (Bedinger and Reed, 1961; Bedinger and Jeffery, 1964; Ackerman, 1996). This earlier interpretation of flow direction changed with subsequent decreasing groundwater levels from irrigation use and construction of a lock and dam system along the river in 1967. Several numerical models in the past two decades were developed using river-package simulations, with results suggesting that streams in Arkansas are volumetrically important sources of recharge to aquifers (Mahon and Ludwig, 1990; Mahon and Poynter, 1993; McKee and Clark, 2003; Reed, 2003; Stanton and Clark, 2003). Reed (2003) depicted flow from model cells along the Arkansas River into the Mississippi River Valley alluvial aquifer throughout parts of southeast Arkansas. Stanton and Clark (2003) also depicted river model cells in southeastern Arkansas as a primary source of recharge to the Mississippi River Valley alluvial aquifer.

The degree of hydraulic connection between streams and alluvial aquifers in Arkansas is dependent on the hydraulic conductivity of the streambed materials, the hydraulic gradient between the two water bodies, and the extent to which the stream is incised into the aquifer (Ackerman, 1996; Barlow and Leake, 2012). Barlow and Leake (2012) noted that thick, silty streambeds (such as that of the Arkansas River) will tend to reduce the rate of flow between a stream and aquifer, while simultaneously increasing the hydraulic gradient between the two water bodies.

\section{Methods}

A general reconnaissance of existing wells in the study area was conducted in the summer of 2010. The reconnaissance included identification and location of existing wells; collection of water-level data (where accessible); and field measurement of specific conductance, water temperature, and $\mathrm{pH}$. Water-quality information was sparse for the Arkansas River Valley alluvial aquifer in the study area, and no data existed for most of the constituents listed in the Federal drinking-water standards and health advisories (U.S. Environmental Protection Agency, 2009). Water samples were collected from 10 wells on July 14 and 15, 2010, and analyzed for major cations, anions, and trace metals; 6 of the 10 samples also were analyzed for pesticides. Samples were analyzed by the USGS National Water Quality Laboratory in Denver, Colorado, following procedures for major ions and trace metals (Fishman, 1993; Garbarino, 1999) and for pesticides (Sandstrom and others, 1992; Furlong and others, 2001).

Estimated concentrations for some constituents are noted by an "E" in front of the concentration. Concentrations are marked as estimated for cases in which the concentration is between the long-term method detection limit and the laboratory reporting limit (Childress and others, 1999). Because there is a 95-percent confidence level that only 1 percent of concentrations above the long-term method detection limit are false positives, estimated concentrations carry a large degree of accuracy and confidence.

Protocols for instrument calibration (Radtke and others, 2005; Wilde, 2006; Ritz and Collins, 2008) and equipment cleaning (Wilde, 2004) were followed to maintain proper quality assurance and quality control of water-quality data associated with all sampling events. A stainless-steel, positivedisplacement pump with Teflon impellers was used to sample wells that lacked dedicated pumps. Two replicate samples and one blank sample were collected during the sampling event. All results from the quality assurance/quality control sample data indicated that cleaning procedures were adequate in preventing cross contamination of samples and that the laboratory results were reproducible.

Historical data for approximately 155 observation wells in the study area were extracted from the USGS National Water Information System database (U.S. Geological Survey, 2010). The wells contained information related to lithologic, hydrologic, and water-quality data collected dominantly for the period from 1957 through 1972. For some wells, abundant data were available, whereas other wells included limited and sporadic collection of hydrologic and water-quality data. Most of these wells were abandoned and fewer than 10 were found during the reconnaissance. Precipitation data were obtained from a nearby, quality-controlled weather station at Fort Smith Regional Airport near Fort Smith, Ark. (National Oceanic and Atmospheric Administration, 2010), located about $4 \mathrm{mi}$ southwest of the Trimble Lock and Dam, for comparison of mean monthly and mean annual precipitation (1957-72) to the well hydrographs. Data related to river stage upstream from the Trimble Lock and Dam were provided by the U.S. Army Corps of Engineers in Little Rock, Ark.

Cumulative precipitation departure was used to evaluate the temporal correlation of precipitation with groundwaterlevel response. Cumulative precipitation departures can support the analysis of short-term hydrologic effects on groundwater such as declines or recharge response relating to precipitation trends (Kresch, 1994; Stogner, 2000; Weber and Stewart, 2004). Cumulative departures of monthly and annual values were calculated from mean-monthly and mean-annual values based on the period of record that matched the available historical water-level data; therefore, cumulative monthly and annual departures represent the excess or deficiency of total inches of precipitation compared to that which would have fallen if average conditions had prevailed during the period of record (Kresch, 1994).

Lithologic data from historical well logs were used to calculate percent sand in the lithologic profile. Percent sand was determined by dividing the continuous sand (including some occurrence of fine gravel) accumulation near the basal section of each well by the total depth of the well; this fraction was 
Lithology, Hydrologic Characteristics, and Water Quality of the Arkansas River Valley Alluvial Aquifer

multiplied by 100 to obtain sand-percentage values. Above the continuous sand representing the groundwater production zone were sequences of alternating silt and clay, which were interpreted as confining layers from a water-production perspective.

\section{Lithology}

Lithologic logs from the historical data for the study area were used to assess the thickness of the coarser sediments serving as the water-producing zone. The Arkansas River Valley alluvial deposits generally are represented by a coarsening downward sequence with silts and clays at the surface and coarse sand and fine gravel near the base of the alluvium. Logs of observation wells drilled from 1957 through 1959 in the study area were used to assess local stratigraphy, including variation in the thickness and extent of the water-producing zone. Lithologic logs from historical data for the study area also were compared to drillers' logs of wells installed for public-supply water in the city of Dardanelle.

Dardanelle serves as an important location from a comparative analysis because of the Arkansas River Valley alluvial aquifer's proven, sustainable production and serving as sole source of public-supply water. Dardanelle supplies a population of approximately 5,500 , in addition to supplying water to local industrial and commercial users (Bill Smith, Dardanelle Water Works, oral commun., 2010). A review of data from 2003 through 2009 revealed annual production increasing from 415 to $820 \mathrm{Mgal}$, respectively, from 12 wells completed at depths ranging from approximately 60 to $69 \mathrm{ft}$ in the Arkansas River Valley alluvial aquifer (Bill Smith, Dardanelle Water Works, written commun., 2010). All wells were in an area of approximately $1 \mathrm{mi}^{2}$, and each well was pumped at a rate of approximately $200 \mathrm{gal} / \mathrm{min}$. Thus, a comparison of stratigraphy between the areas provides a preliminary indication of the water-supply potential for the Arkansas River Valley alluvial aquifer in the study area.

In the study area, the presence of gravel was noted on only 4 of 59 drillers' logs. The total depth of the 59 wells ranged from 25 to $52 \mathrm{ft}$, with a mean depth of $42 \mathrm{ft}$. The thickness of the basal sand (including some occurrence of fine gravel) representing the water-producing zone ranged from 5 to $47 \mathrm{ft}$, with a mean thickness of $29 \mathrm{ft}$. In the Dardanelle area, gravel was noted in the basal section for 11 of 12 wells. The thickness of the sand/gravel, water-producing zone ranged from 8 to $69 \mathrm{ft}$ with a mean thickness of $21 \mathrm{ft}$. The lithology in the Dardanelle area suggests a more permeable and higheryield water-producing zone than from wells in the Van Buren area based on the greater proportion of gravel - indicating the potential for greater water production in the Dardanelle area as compared to the Van Buren area-although mean thickness of the water-producing zone was similar and slightly higher in the study area. It should be noted that groundwaterproduction wells in the Dardanelle area were all within $0.8 \mathrm{mi}$ of the Arkansas River; whereas, wells in the study area near Van Buren ranged from 0.25 to $2.5 \mathrm{mi}$ from the river. Because channel deposits next to the river generally contain coarser material, the comparative lack of sites nearer the river in the Van Buren area potentially could bias the comparison of potential production capacity for alluvial sediments in the Dardanelle and Van Buren areas.

Anecdotal information and data gathered for this study suggest a less productive zone for large parts of the alluvium within the study area as compared with Dardanelle. Wells in the Dardanelle area were pumped on a continual basis throughout the year with an average individual pumping rate of approximately $200 \mathrm{gal} / \mathrm{min}$, and all wells are within an approximate $1 \mathrm{mi}^{2}$ area, whereas only irrigation wells are used in the Van Buren area, and these wells are used only during the dry season in summer months. Even with the lower overall use, some farmers in the Van Buren area report that irrigation wells produced yields sufficient for pivot irrigation (generally greater than $500 \mathrm{gal} / \mathrm{min}$ ) for approximately 1-2 weeks of pumping, at which time yields drop to less than $200 \mathrm{gal} / \mathrm{min}$; rates that are inadequate for pivot irrigation. After shutting down the wells for 2-3 days, water levels were reported to rebound to a degree that pumping could resume. This situation suggests that less permeable boundaries are encountered by an expanding cone of depression during pumping of the well.

Several farmers in the study area and personnel at the Van Buren County Cooperative Extension Service confirmed this observation and also reported that several exploratory wells had been drilled in various locations in the study area with initial yields that were inadequate for irrigation use. These wells typically encountered thick sequences of fine material (silt, clay, and sandy clay) that lacked the necessary hydraulic conductivity for transmitting water at rates necessary for irrigation. Discussions with farmers in the study area that practice dry-land farming confirmed that drilling of exploratory wells produced yields inadequate for irrigation.

Several different depositional environments are found in meandering stream flood plains with associated deposits that vary in grain size and resulting hydraulic characteristics, including natural-levee, backswamp, point-bar, swale, and channel-fill deposits. Point-bar deposits are formed on the concave (inside) bank of a stream meander by the vertical and lateral accretion of coarse-grained sands and gravels; point bars represent the most permeable deposits in an alluvial valley (Bedinger and Reed, 1961). Point bars are separated by swales, which are clay- and silt-filled depressions on the convex (outside) bank of the meander that tend to collect low-permeability deposits. Natural-levee deposits form at the margins of a stream channel where flooding causes overbank flow; as water leaves the channel, a drop in hydrodynamic energy results in deposition of coarser-grained materials, usually dominated by sand with a resulting deposit of relatively high permeability. Over time as a stream meanders within a flood plain, some stream segments, particularly bends, can be 
cut off and isolated, forming the characteristic oxbow lake, which generally is filled with clays and silts during floods. These channel-fill deposits commonly are referred to as "clay plugs," because of the impermeable nature of the fill deposits, and represent some of the least permeable deposits in an alluvial stream system (Bedinger and Reed, 1961).

Drillers' logs for the study area included general descriptions and thicknesses for the distribution of silt, clay, and sand fraction within each boring. The percent sand (and gravel, where present) representing the dominant water-producing zone was calculated from all available drillers' logs in the study area. The resulting sand percentages for all borings were overlain onto an orthophotograph to examine the areal distribution of sand percentage in relation to geomorphologic features of the flood plain in the study area (fig. 2). Percent sand, rather than the thickness of the sand producing zone, was used to provide a better indication of the sand-rich point-bar and levee deposits compared to the clay-rich deposits associated with backswamps and swales. Identification of these depositional environments can provide important information related to permeability and recharge potential. Several abandoned channels were identified on the orthophotograph, and a consistent trend was noted between the occurrence of greater percent sand in wells near the river and on the concave (point bar) side of abandoned channels compared to a lower percent sand on the convex side of the channel, which is generally dominated by less permeable deposits associated with swales and clay- and silt-filled depressions. Modern-day, pointbar deposits are recognizable on figure 2 as whitish bands (lighter colored sands and gravels) on the concave side of the present-day, Arkansas River meander belt. The distribution of these deposits of varying permeability generally agrees with anecdotal information in regard to the distribution of productive wells in the area and the occurrence and close proximity of less permeable boundaries encountered by expanding cones of depression during irrigation well pumping in the study area. This finding may prove useful for identifying optimum areas for drilling irrigation wells along the extent of the Arkansas River Valley alluvial aquifer.

\section{Hydrologic Characteristics}

Between 1957 and 1972, water levels were monitored in approximately 150 historical wells in the study area prior to and after completion of the Trimble Lock and Dam on the Arkansas River (fig. 1) as a joint effort on the part of the USGS, the USCE, and the AGC. Collection of water-level data was sporadic for many of the wells and ranged from biweekly to monthly, with some wells having only a 2-year period of record; whereas, water levels were measured over the entire period of record for many other wells but often with large data gaps at various times throughout the period of measurement. Although data were inconsistent throughout the period of record, potentiometric surfaces constructed from water levels showed a dominant south to southeast direction of flow toward the river for the spring and fall of 1958 through 1972. No major changes occurred in the potentiometric surface following dam construction and filling of the pool; however, minor variations in water levels can occur locally near the river that may not be reflected in the regional potentiometric surface. For this reason, individual hydrographs were inspected to further investigate potential changes in groundwater levels resulting from installation of the dam.

Hydrographs were created using wells with the most consistent period of measured water levels and compared to precipitation and river stage data. Water levels in most wells generally showed similar changes over the period of record. Four representative hydrographs for wells with the longest and most consistent period of record are shown in figure 3. An overall decline in water levels was noted from the earliest period of record until about April through October 1967 (a time when water levels in most wells were the lowest for the period of record). Although seasonality is reflected in the water-level peaks and troughs during this period of decline, the trend was steadily downward over a period of approximately 10 years. Water levels in eight wells (including the four representative wells shown in fig. 3) with the longest period of record showed overall declines ranging from 9.3 to $15.6 \mathrm{ft}$ during this period, with a median decline of $11.9 \mathrm{ft}$. Following the lowest water levels in 1967, water levels rapidly increased within a short period of approximately 6-10 months up to the late spring and summer period of 1968. These relatively rapid rises in water levels for eight wells with the longest period of record ranged from 5.2 to $10.2 \mathrm{ft}$, with a median of $8.4 \mathrm{ft}$.

An activity associated with this study was to assess the influence of the Arkansas River on groundwater levels. If the river has a strong hydraulic connection with the Arkansas River Valley alluvial aquifer, possible lowering of the groundwater table resulting from irrigation pumping would be expected to induce flow from the river into the wells with expanding cones of depression. Even where pumping induced influx was not a major factor, natural influx of river water should result when river stage altitudes are greater than groundwater altitudes in the study area, given a strong hydraulic connection. River stage upstream from the dam increased approximately $6 \mathrm{ft}$ following dam completion (Glen Riable, Little Rock District U.S. Army Corps of Engineers, written commun., 2010). Concerns associated with a large influx of water from the river include an increase of groundwater chloride concentrations during the summer months when chloride concentrations are greatest in the river and migration of contaminants into the aquifer from potential chemical spills on the river. Conversely, the lack of a strong hydraulic connection between the aquifer and the river requires sufficient recharge by precipitation and adequate aquifer storage to maintain sustainable pumping from continuing irrigation use and future potential public-supply water. 


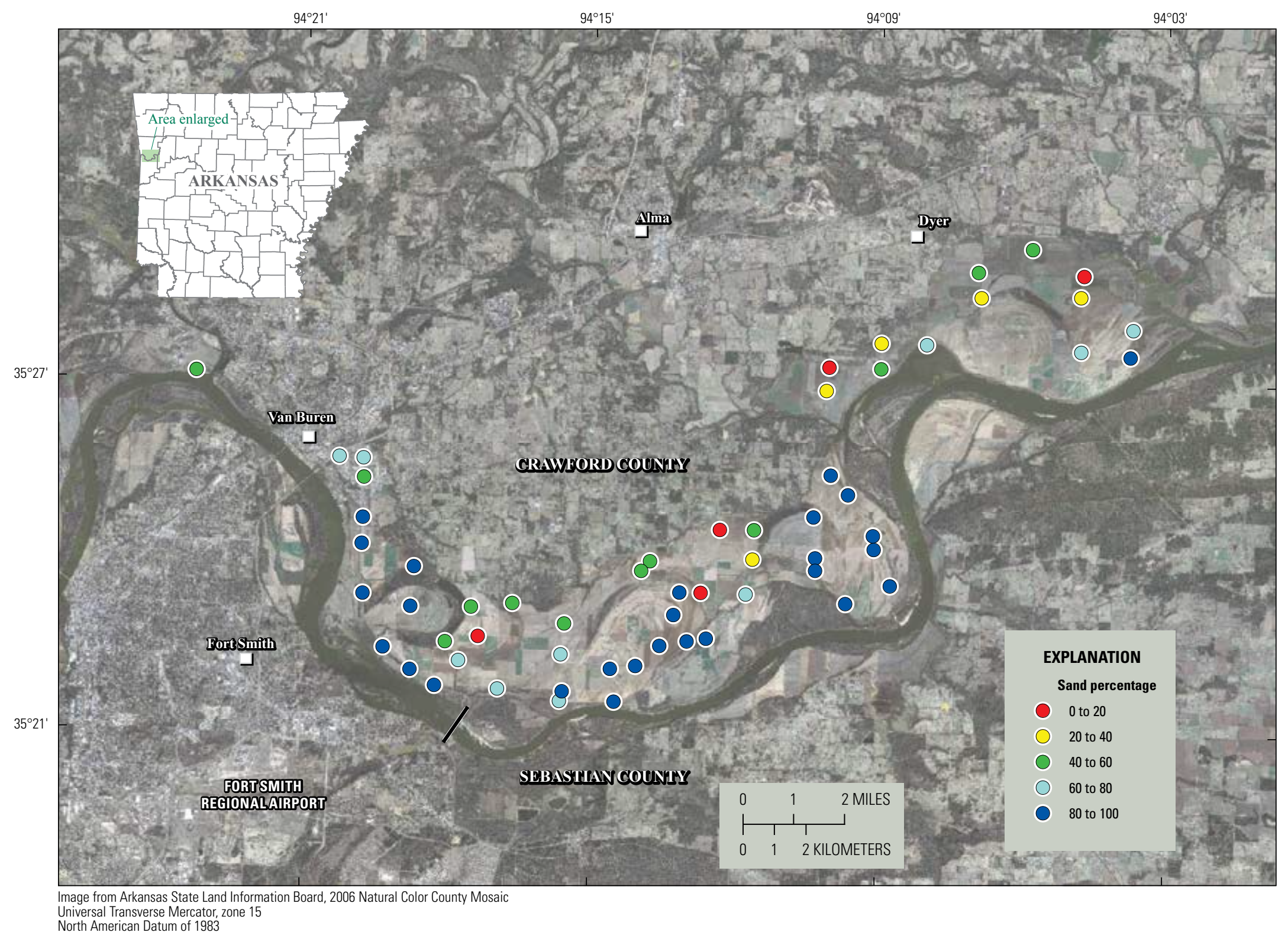

Figure 2. Sand percentage derived from drillers' logs overlain onto an orthophotograph near the Van Buren study area, Arkansas. 


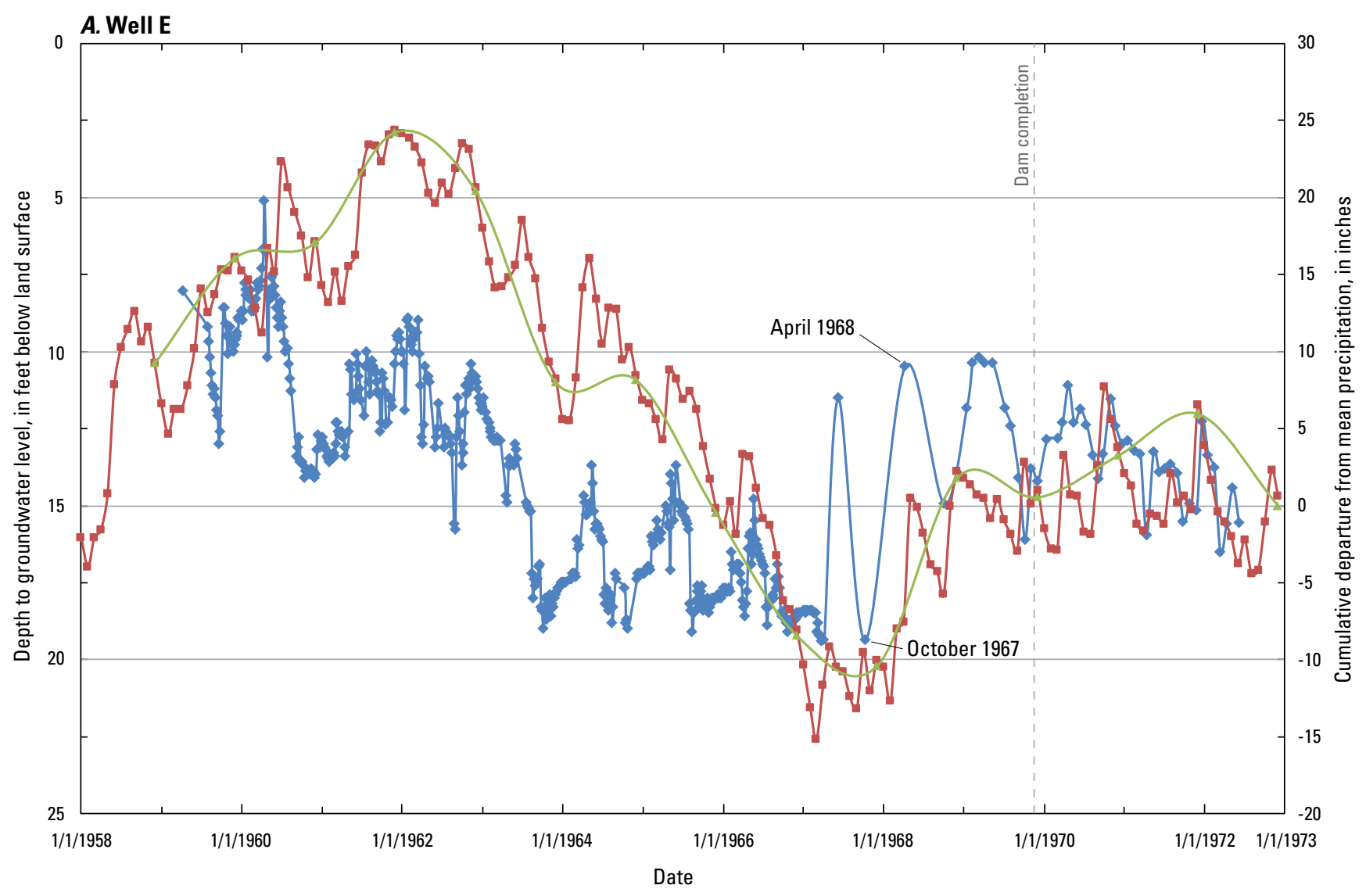

\section{EXPLANATION}

Groundwater level, in feet below

land surface-Well E, station

number 352251094153202 (fig. 1)

Departure from mean precipitation

(1958-72), in inches

$\rightarrow$ Monthly

$\longrightarrow$ Annual

Figure 3. Groundwater level and cumulative departure from mean monthly and mean annual precipitation in the Van Buren study area, Arkansas. 


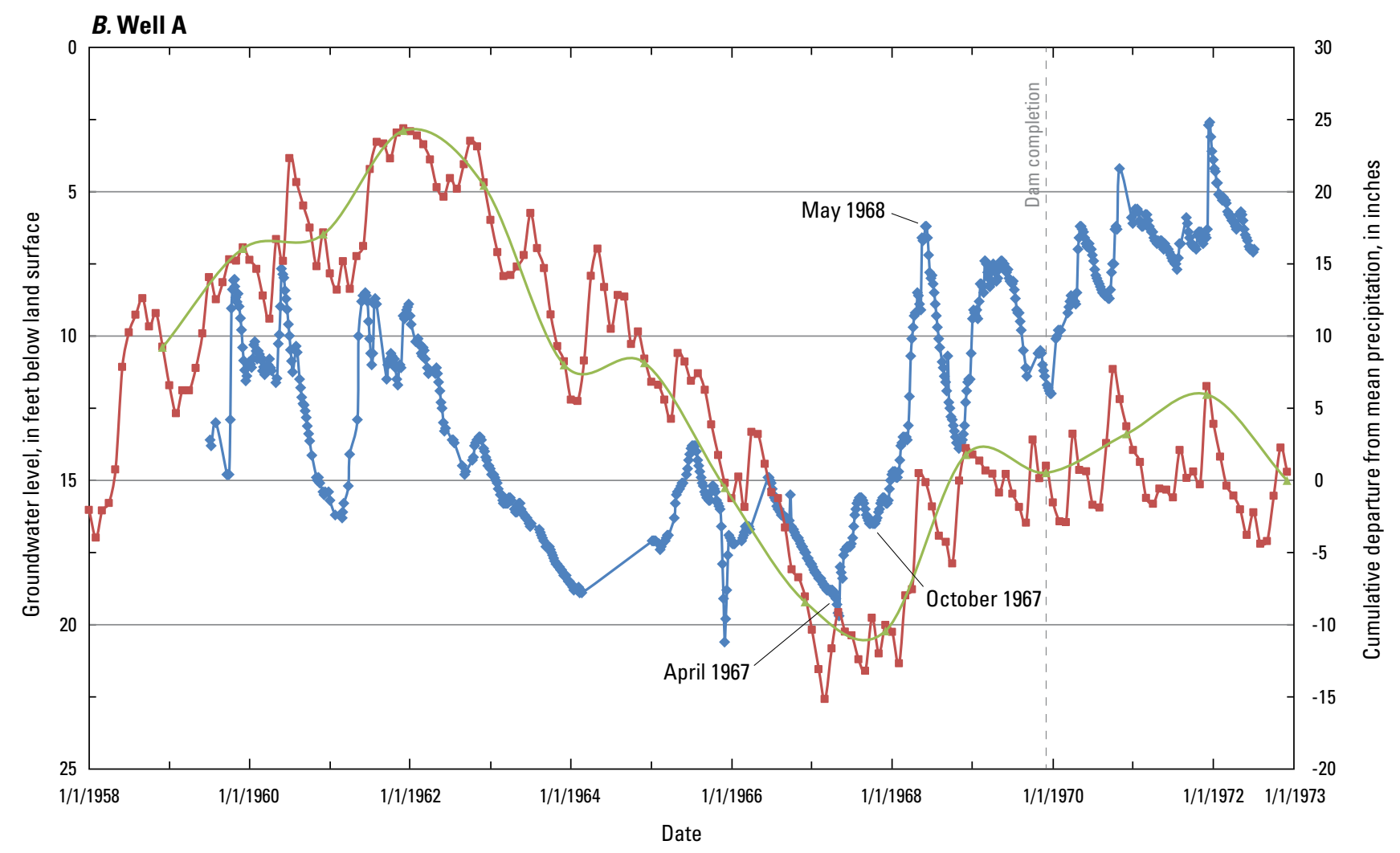

EXPLANATION

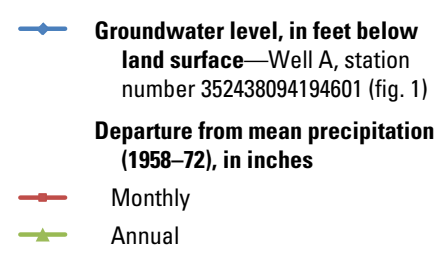

Figure 3. Groundwater level and cumulative departure from mean monthly and mean annual precipitation in the Van Buren study area, Arkansas.-Continued 


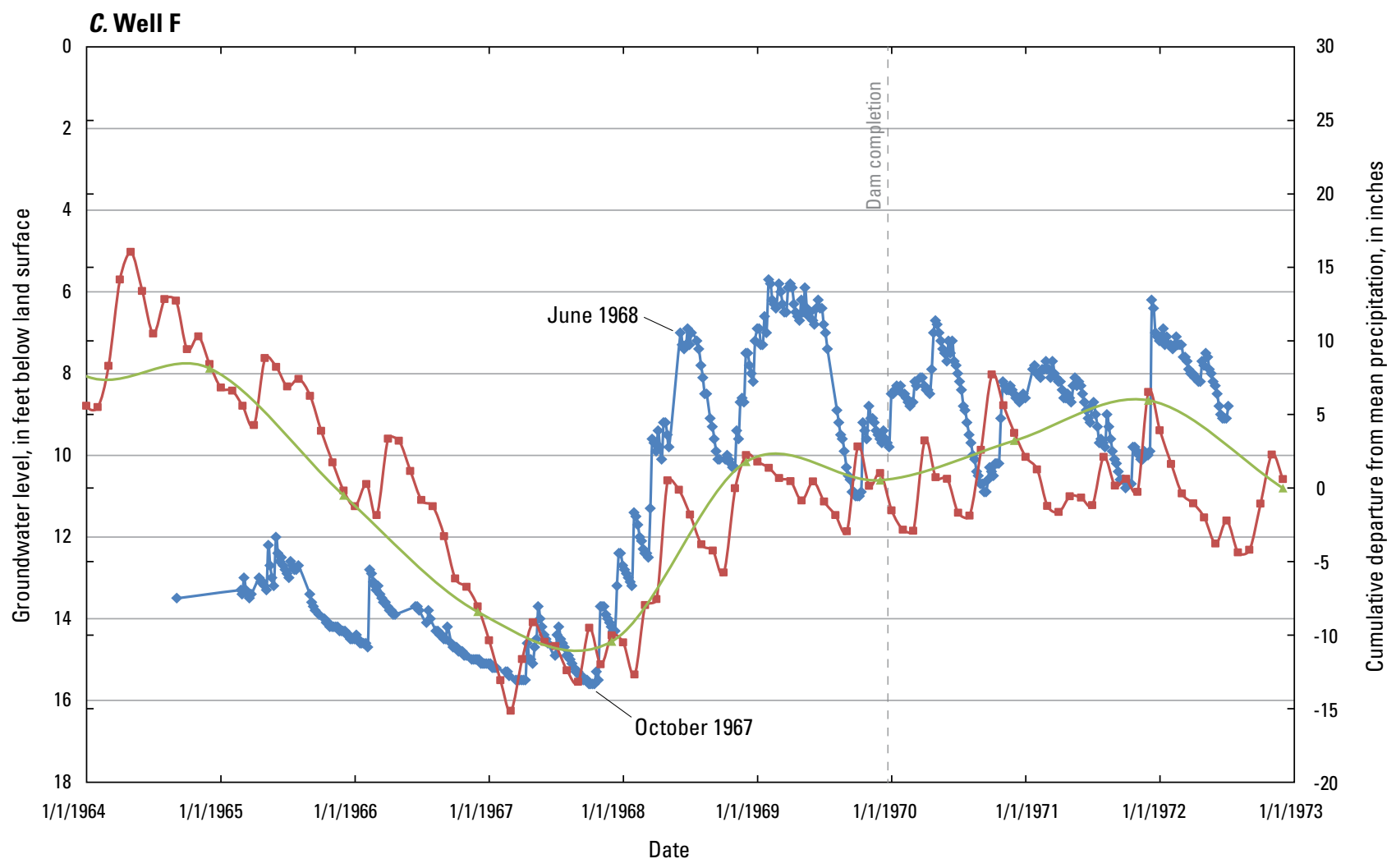

EXPLANATION

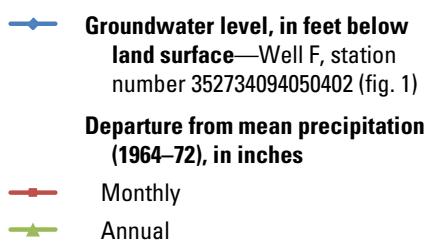

Figure 3. Groundwater level and cumulative departure from mean monthly and mean annual precipitation in the Van Buren study area, Arkansas.-Continued 


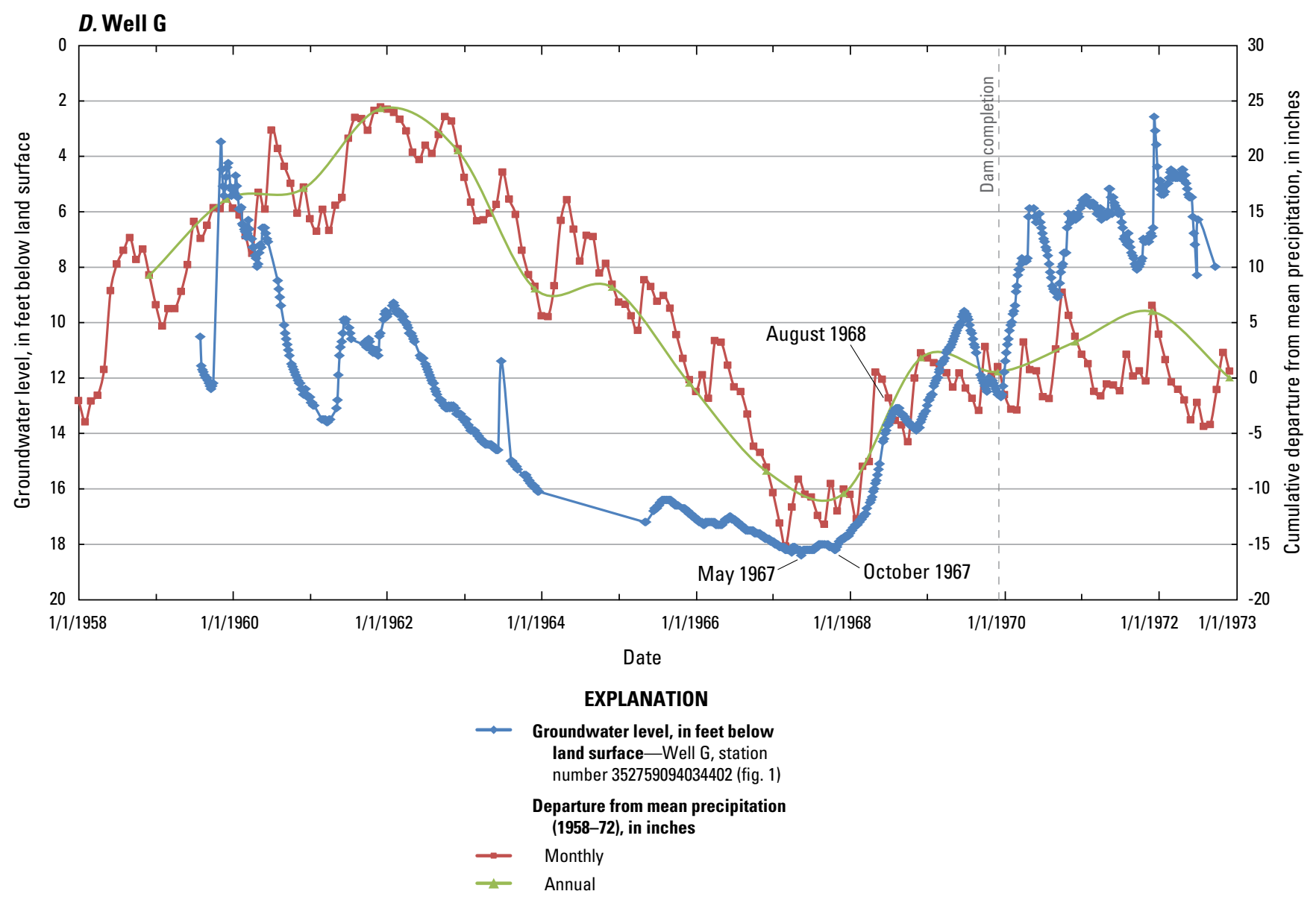

Figure 3. Groundwater level and cumulative departure from mean monthly and mean annual precipitation in the Van Buren study area, Arkansas.-Continued 
A cursory inspection of the hydrographs (fig. 3) initially suggested that the relatively rapid rise in the water table after 1967 might have resulted from the installation of Trimble Lock and Dam on the Arkansas River (fig. 1); however, that rise occurred before the Trimble Lock and Dam was completed (December 1969), with the design pool stage of approximately $390 \mathrm{ft}$ NGVD 29 reached in April 1970. Previous to dam completion and filling of the pool, the river was allowed to flow freely with no deviation from its natural stage (Glen Riable, Little Rock District U.S. Army Corps of Engineers, oral commun., 2010). Comparison of precipitation data to water levels generally shows a good relation. Long-term decreases in water levels from the earliest period of record to 1967 followed by a sharp rise in water levels and steady increases in water level are concurrent with the general trend of cumulative departure from mean annual precipitation (fig. 3). Short-term peaks and troughs in the water-level data within the long-term trends generally fit the cumulative departure from mean monthly precipitation, reflecting the rapid response of groundwater levels to precipitation events. Intervals of sparse measurements limit the ability for comparing some timeframes within the period of record and for showing potential perturbations in water levels from precipitation events over the period of missing water-level data.

Short-term perturbations in water levels are best demonstrated by evaluation of responses during individual rain events. During the study, a short-duration, real-time monitoring program was established using an abandoned well in the study area. Water levels were collected using a pressure transducer (Freeman and others, 2004) on a 15-minute interval, and daily averages were calculated from these values for the period from May 28 through August 5, 2010. Responses to rain events are apparent from review of the water-level data, with the strongest response during a 2.5 -inch rain event that occurred on July 9, 2010 (fig. 4). Water levels began to rise immediately following this rain event and continued rising

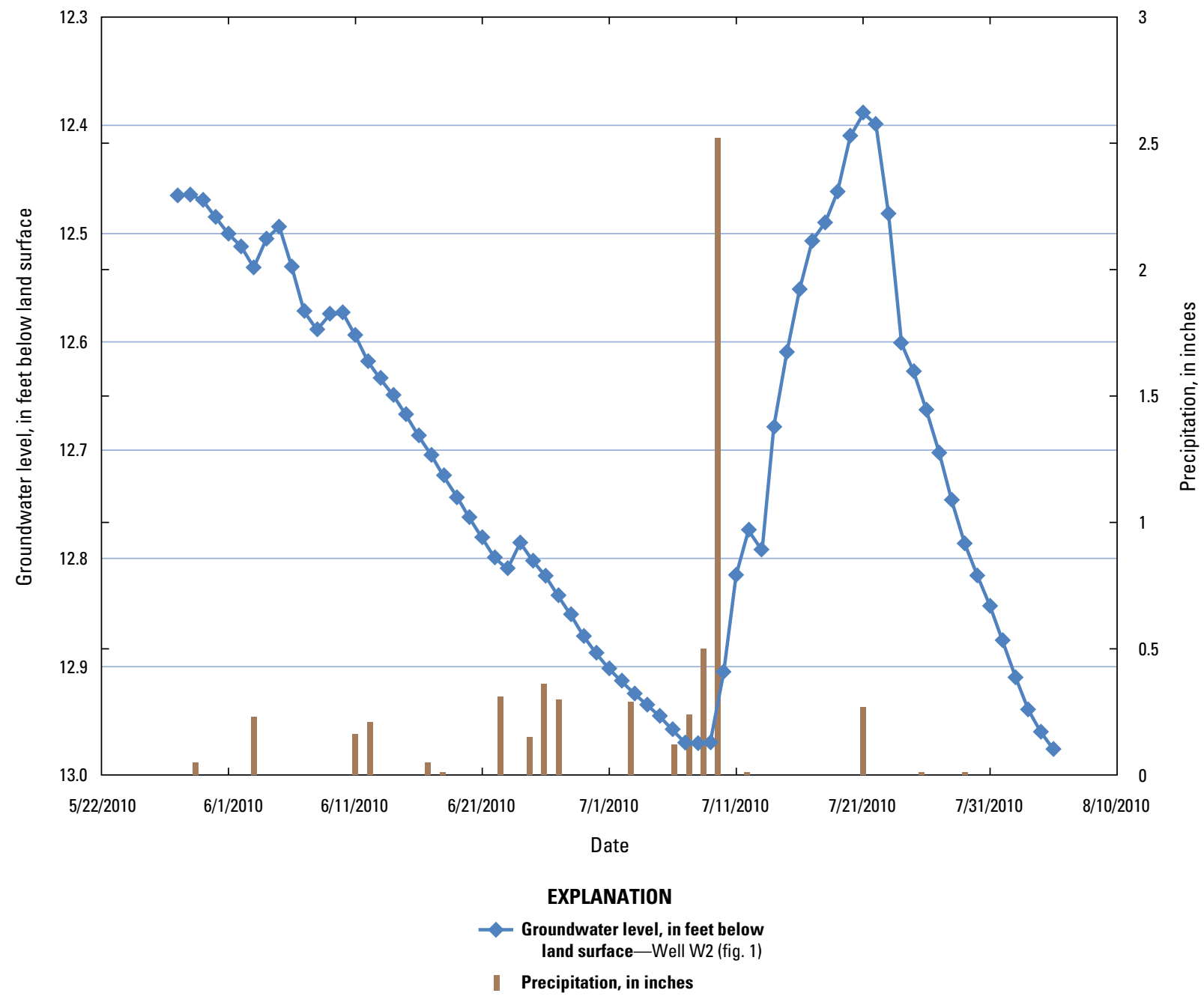

Figure 4. Groundwater level and precipitation data for real-time site in the Van Buren study area, Arkansas. 
to a high of $12.4 \mathrm{ft}$ on July 21 from a low of $13 \mathrm{ft}$ below land surface on July 8, 2010. Water levels rose approximately $0.6 \mathrm{ft}$ in 13 days. Conversely, river stage did not change from May through August, except for a drop of approximately $3 \mathrm{ft}$ from June 12 to June 19 and a drop of $2 \mathrm{ft}$ from July 6 to July 10 in response to releases at the dam. Thus, the rapid rise of water levels following the large rain event on July 9, 2010, was during a period when river stage was generally declining. This exercise demonstrates the rapid response time and large overall water-level increase for a single rain event for one well in the study area.

Although a general relation was established between precipitation and water levels for the entire period of record, the assessment of dominant influences on the groundwater table following completion of the Trimble Lock and Dam presents challenges because subsequent rises in pool levels immediately following completion of the dam generally occurred simultaneously with increasing annual-departure precipitation during that period of record. For example, the hydrograph for well A (fig. 3B) shows a sharp water-level increase after dam completion with an overall increase for the remainder of the period of record, which suggests that either rising river stage or generally increasing cumulative precipitation might be the source of the water-level increase. Inspection of 11 well hydrographs with the most continuous data following dam completion revealed increasing and decreasing water levels following completion of the dam, although graphs of annual-departure precipitation showed a generally increasing trend after December 1969 (completion of the dam). Of these 11 well hydrographs, 5 wells were located approximately 0.8-4.5 mi upstream from the dam, whereas the other 6 wells were 2.5-18 mi downstream from the dam; therefore, the 6 downstream wells would be expected to show minimal to no effects to water levels after dam completion even if the river was well connected with the Arkansas River Valley alluvial aquifer. After December 1969, water levels showed overall increasing trends in 4 of the 5 upstream wells, whereas water levels showed increasing trends in only 2 of the 6 downstream wells - the remaining hydrographs had water-level trends that were flat-lying or decreasing. Therefore, no clear pattern relative to dam installation and connectivity of the aquifer and river is apparent, although a greater percentage of well hydrographs had increasing water-level trends upstream from the dam.

To evaluate the dominant controls on water-level fluctuations after installation of the dam, hydrographs for four wells upstream from the dam were compared to river stage and cumulative departure from mean monthly precipitation (fig. 5). Distances of these wells from the river ranged from 0.4 to $0.9 \mathrm{mi}$ (fig. 1). The well closest to the dam and $0.7 \mathrm{mi}$ from the river (fig. $5 \mathrm{~A}$; well D on fig. 1) had a water-level altitude that averaged approximately $10 \mathrm{ft}$ lower than the river-stage altitude for the period of record following completion of the dam (December 1969 through June 1972). Water levels for this well over this period of time should have been affected to a greater degree because of the close proximity of the well to the river $(0.7 \mathrm{mi})$ and the large gradient $(10 \mathrm{ft})$ between the river-stage altitude and water-level altitude. Increases and decreases in monthly departure precipitation compare closely to increases and decreases in water level (fig. $5 \mathrm{~A}$ ) regardless of river stage, and the overall water-level trend is generally flatlying, with no apparent effects from rising river stage (overall increase in river stage of approximately $6 \mathrm{ft}$ ). Water levels generally declined with declines in cumulative departure from mean monthly precipitation for all wells (fig. 5A-D), although river stage continued to slowly rise following dam completion. This relation generally is repeated for all of the hydrographs - regardless of distance from river-with increases and decreases in water levels comparing to increasing and decreasing positive departure from mean monthly precipitation, although river stage continued to rise. An interesting relation is found in figure $5 D$ (well A on fig. 1), which demonstrates the overriding effects of precipitation. Cumulative departure in mean annual precipitation steadily rose following dam completion (fig. 3) as had river stage (fig. 5) during this same time period. A review of figure $3 B$ (well A in fig. 1), while revealing the close relation between water level and precipitation, showed an increase in water level immediately following dam completion and filling, thus indicating possible riverstage effects. However, the hydrograph for well A depicted in figure $5 D$ reveals that groundwater altitudes are actually higher than river stage and could not be directly affected by rising river stage. Therefore, although the sudden increase in water levels following dam completion initially suggested possible influence by rising river stage for well A, further analysis applying river stage altitude shows that water-level responses, similar to other wells, correlate closely to changes in precipitation with minimal discernible effects from river stage.

Whereas most wells upstream from the dam show little effect from river stage following dam completion, well $\mathrm{C}$ (fig. $5 B$ ) appears to have a better relation with river stage. Although precipitation still appears to influence the peaks and troughs for the water-level graph, the water levels follow the general trend of rising river stage. There also was limited geochemical evidence for possible river-water influence at well $\mathrm{C}$, as chloride concentrations in the general vicinity of well C were slightly elevated compared to other wells in the study area, which is discussed in further detail in "Discussion of River Water and Groundwater Interaction." However, it should be noted that the overall increasing water-level trend in well $\mathrm{C}$ (fig. $5 B$ ), including the peaks and troughs, is similar to that for well A (fig. $5 D$ ), which was shown to have minimal effects from river stage. 


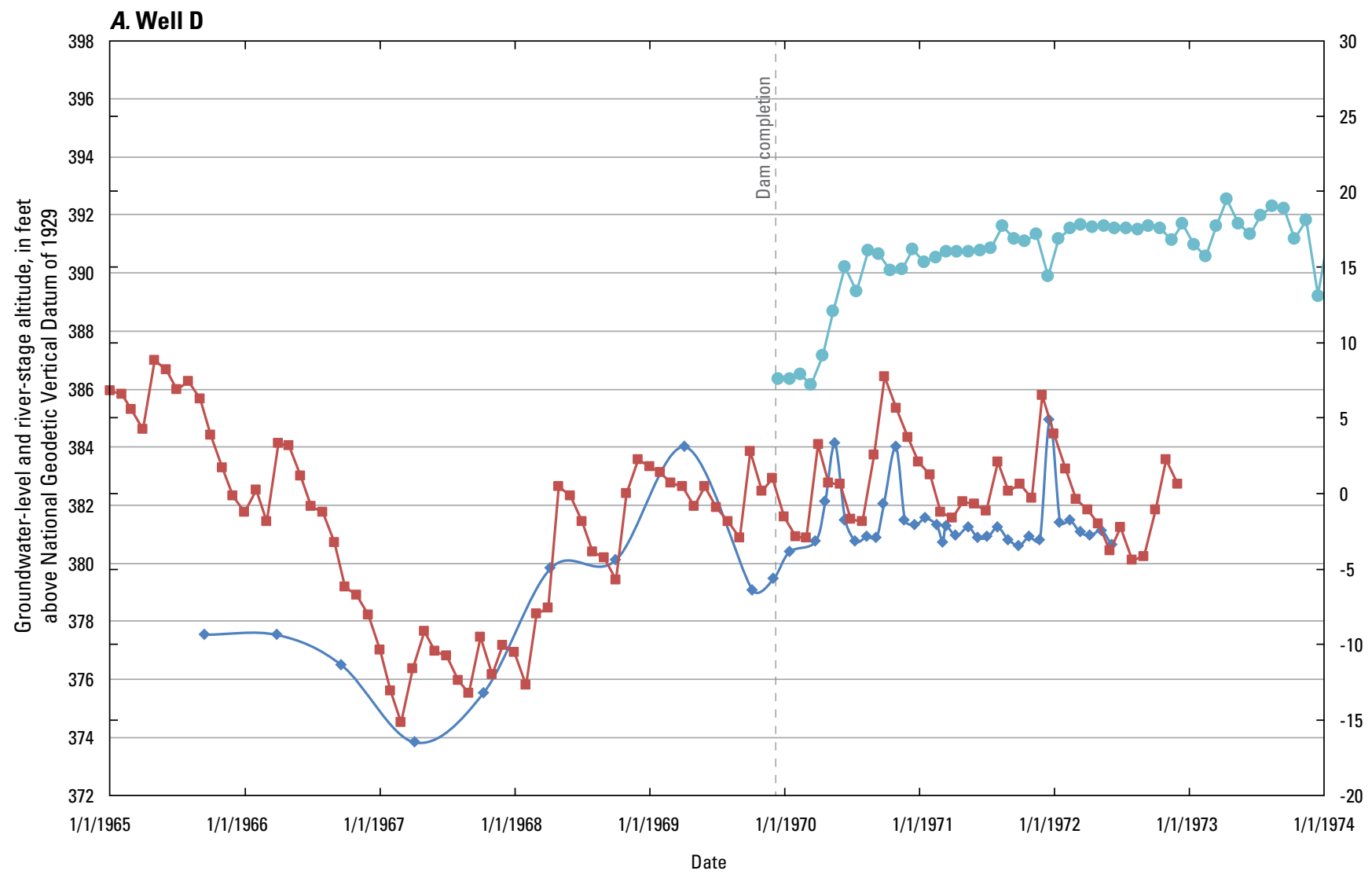

Figure 5. Groundwater level, river stage, and cumulative departure from mean monthly precipitation for wells upstream from the James W. Trimble Lock and Dam 13 in the Van Buren study area, Arkansas. 


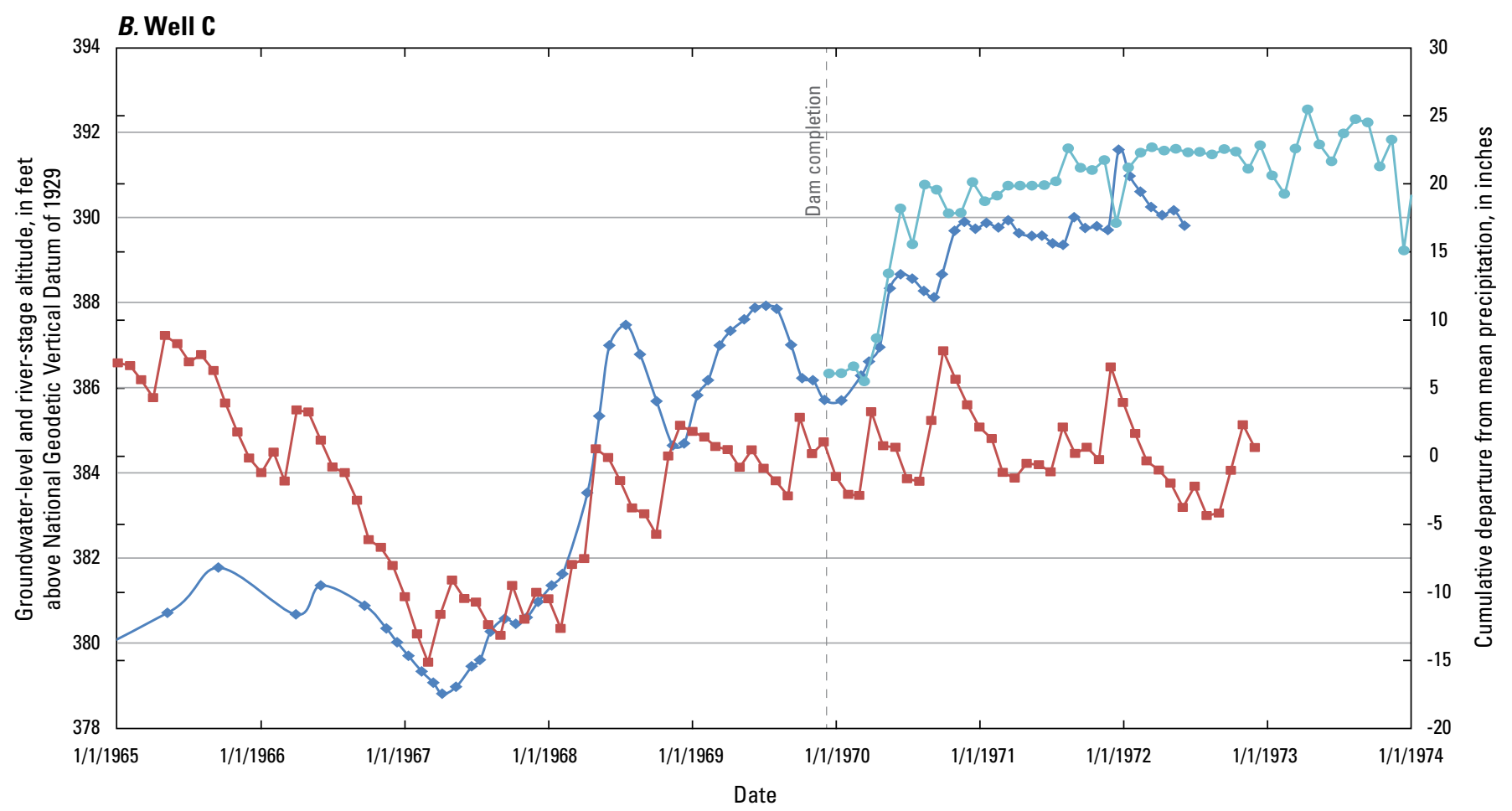

EXPLANATION

Water-level altitude, in feet above National

Geodetic Vertical Datum of 1929

$\leadsto$ Groundwater level-Well C, station

number 352333094195002 (fig. 1)

$\rightarrow \quad$ River stage-Arkansas River

$\rightarrow$ Departure from mean monthly precipitation (1965-72), in inches

Figure 5. Groundwater level, river stage, and cumulative departure from mean monthly precipitation for wells upstream from the James W. Trimble Lock and Dam 13 in the Van Buren study area, Arkansas.-Continued 


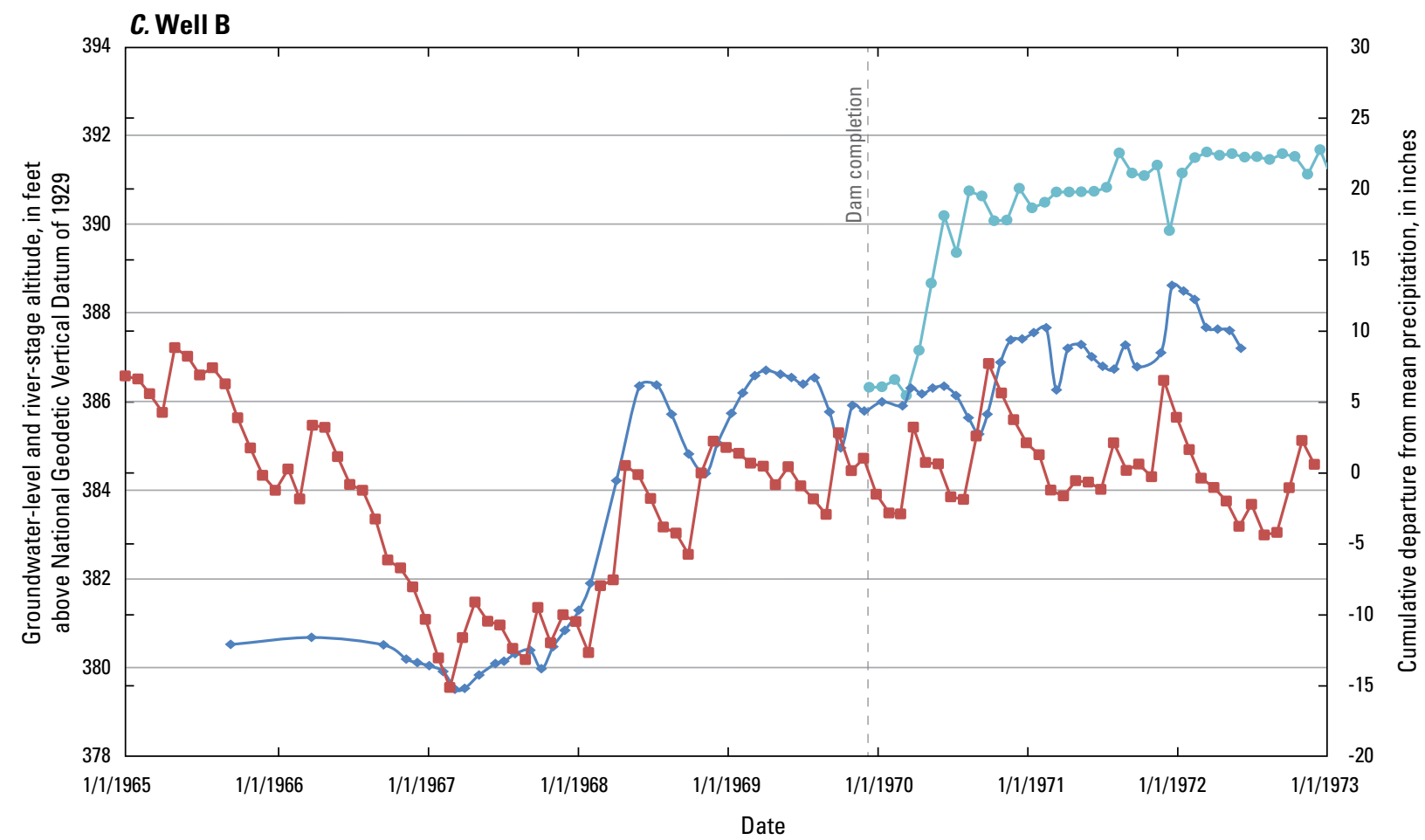

EXPLANATION

Water-level altitude, in feet above National Geodetic Vertical Datum of 1929

— Groundwater level—Well B, station number 352346094191701 (fig. 1)

- - River stage-Arkansas River

$\rightarrow$ Departure from mean monthly precipitation (1965-72), in inches

Figure 5. Groundwater level, river stage, and cumulative departure from mean monthly precipitation for wells upstream from the James W. Trimble Lock and Dam 13 in the Van Buren study area, Arkansas.-Continued 


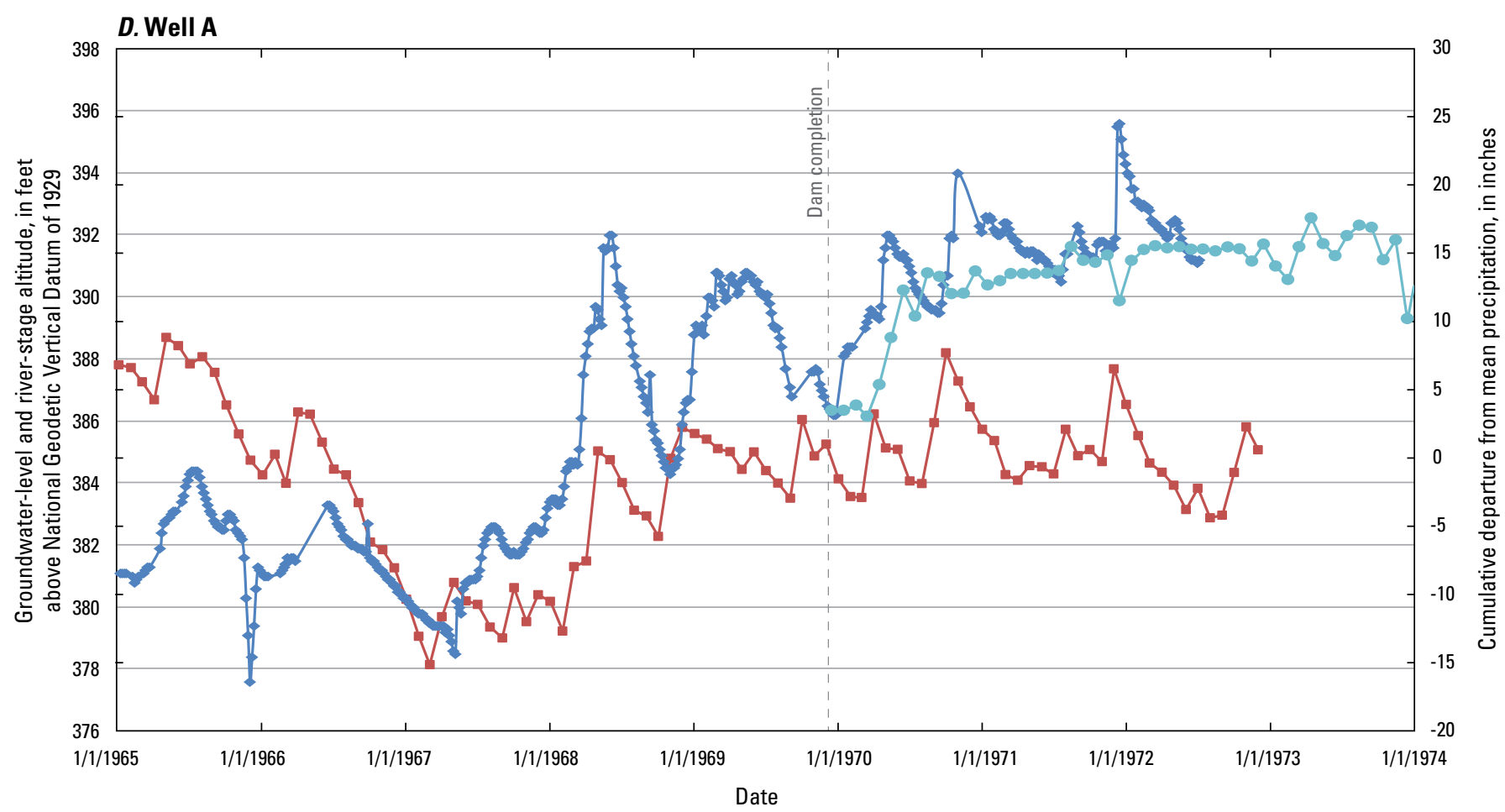

EXPLANATION

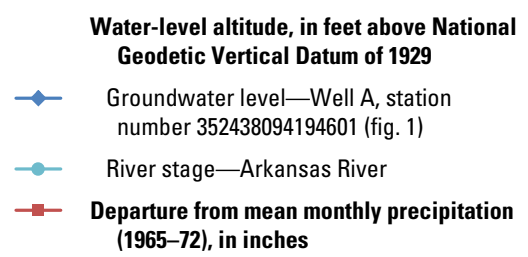

Figure 5. Groundwater level, river stage, and cumulative departure from mean monthly precipitation for wells upstream from the James W. Trimble Lock and Dam 13 in the Van Buren study area, Arkansas._Continued 


\section{Water Quality}

\section{General Geochemistry and Water Type}

Ten wells in the study area (fig. 1) were sampled to characterize water quality, water type, and geochemistry of the Arkansas River Valley alluvial aquifer (app. 1). Analysis of the water-quality data revealed that groundwater in the study area is a calcium-bicarbonate water type, similar to that of groundwater from the Mississippi River Valley alluvial aquifer in southeastern Arkansas (Kresse and Fazio, 2002) and groundwater from the Arkansas River Valley alluvial aquifer in Dardanelle, Ark. (Kresse and others, 2006). Calcium concentrations ranged from 61 to 135 milligrams per liter $(\mathrm{mg} / \mathrm{L})$, with a mean concentration of $107 \mathrm{mg} / \mathrm{L}$, and bicarbonate concentrations ranged from 211 to $521 \mathrm{mg} / \mathrm{L}$, with a mean concentration of $392 \mathrm{mg} / \mathrm{L}$. Calcium ranged from 60 to 77 percent of the total cations in milliequivalents per liter, and bicarbonate ranged from 71 to 95 percent of the total anions in milliequivalents per liter. Other major cations (sodium and magnesium) and anions (chloride and sulfate) showed substantially lower concentrations compared to calcium and bicarbonate, respectively. Sodium concentrations ranged from 11.3 to $20.3 \mathrm{mg} / \mathrm{L}$, with a mean concentration of $15.6 \mathrm{mg} / \mathrm{L}$; magnesium concentrations ranged from 16.4 to $27.7 \mathrm{mg} / \mathrm{L}$, with a mean concentration of $20.5 \mathrm{mg} / \mathrm{L}$; chloride concentrations ranged from 6.1 to $22 \mathrm{mg} / \mathrm{L}$, with a mean concentration of $15 \mathrm{mg} / \mathrm{L}$; and sulfate concentrations ranged from 2.4 to $47 \mathrm{mg} / \mathrm{L}$, with a mean concentration of $20 \mathrm{mg} / \mathrm{L}$.

Iron concentrations ranged from 155 to 15,500 micrograms per liter $(\mu \mathrm{g} / \mathrm{L})$, with a mean concentration of $4,447 \mu \mathrm{g} / \mathrm{L}$, indicating a general predominance of ironreducing conditions in the aquifer. Iron-reducing conditions similarly were noted in the Arkansas River Valley alluvial aquifer near Dardanelle by Kresse and others (2006). Arsenic concentrations ranged from 0.38 to $6.8 \mu \mathrm{g} / \mathrm{L}$, with a median concentration of $1.3 \mu \mathrm{g} / \mathrm{L}$, and all concentrations were less than the Federal primary drinking-water standard of $10 \mu \mathrm{g} / \mathrm{L}$ arsenic (U.S. Environmental Protection Agency, 2009). Iron concentrations correlated positively to arsenic concentrations with an $\mathrm{R}^{2}$ (coefficient of determination) value of 0.74 (fig. 6). A review of water-quality data from the Dardanelle area (Kresse and others, 2006) also showed a positive correlation between iron and arsenic concentrations with an $\mathrm{R}^{2}$ value of 0.77 and a maximum arsenic concentration of $19 \mu \mathrm{g} / \mathrm{L}$. Kresse and Fazio (2002) hypothesized that the source of elevated dissolved arsenic in groundwater in the Mississippi River Valley alluvial aquifer south of the Arkansas River in southeastern Arkansas was associated with an inorganic source (coprecipitation of arsenic onto iron oxyhydroxides) rather than through past application of arsenical pesticide formulations. Kresse and Fazio (2003) provided preliminary evidence for reductive dissolution of iron oxyhydroxides as the source of elevated iron and arsenic concentrations in the Mississippi
River Valley alluvial aquifer, and detailed studies by Sharif and others $(2008 \mathrm{a}, \mathrm{b})$ confirmed reductive dissolution of iron oxyhydroxides as the source of elevated iron and arsenic concentrations. Holocene-age alluvial deposits contain abundant organic matter, which acts as a substrate and electron donor for microbial processes, resulting in depletion of oxygen and increasing reducing conditions along flow paths in the deeper sections of the aquifer (Kresse and Fazio, 2002; Sharif and others, 2008a,b). The geochemistry of the Arkansas River Valley alluvial aquifer in the study area indicates that reduction of iron oxyhydroxides has resulted in elevated iron and arsenic concentrations in similar fashion to processes in the Mississippi River Valley alluvial aquifer.

Most inorganic constituent concentrations were below Federal drinking-water standards and health advisories. Iron concentrations exceeded the secondary drinking-water regulations $(300 \mu \mathrm{g} / \mathrm{L})$ in 9 of the 10 wells sampled for the study, and manganese concentrations exceeded the secondary drinking-water regulations $(50 \mu \mathrm{g} / \mathrm{L})$ in all 10 wells (U.S. Environmental Protection Agency, 2009). Secondary drinkingwater regulations are unenforceable Federal guidelines regarding taste, odor, color, and other aesthetic effects of drinking water that are not related to human-health concerns.

\section{Pesticides}

Six of the 10 groundwater samples were analyzed for pesticides because of the dominance of agricultural land use in the study area. Three of the six wells were used to irrigate sod farms at the time of sampling, and the remaining three wells were used for row-crop irrigation. Six herbicide compounds and one herbicide metabolite were detected and at least one herbicide was detected in five of the six well-water samples. The compounds detected include tebuthiuron, triclopyr, metolachlor, imazaquin, bentazon, atrazine, and 2-chloro4-isopropylamino-6-amino-s-triazine (deethylated metabolite of atrazine). Tebuthiuron is a broad-spectrum herbicide used in noncropland areas such as ditches, right of ways, fences, and other areas (Extension Toxicology Network, 2012) and was detected at two sites at estimated concentrations of $0.001 \mu \mathrm{g} / \mathrm{L}$. Trichlopyr is a selective systemic herbicide that is used to control woody and broadleaf plants in noncropland areas (Extension Toxicology Network, 2012). Triclopyr was detected in only one well, which at the time of sampling was being used to irrigate corn. Metolachlor and atrazine are used to control broadleaf and grassy weeds in corn, and these herbicides frequently are used together in multiple formulations on corn (Extension Toxicology Network, 2012). Metolachlor was detected at an estimated concentration of $0.01 \mu \mathrm{g} / \mathrm{L}$ in only one well, which also had a detection of atrazine. Atrazine was detected in two samples at estimated concentrations of $0.01 \mu \mathrm{g} / \mathrm{L}$. Imazaquin is a selective preemergent and postemergent herbicide that is used to control grasses and broadleaf plants dominantly in beans (Extension Toxicology Network, 2012) and was detected at an estimated 


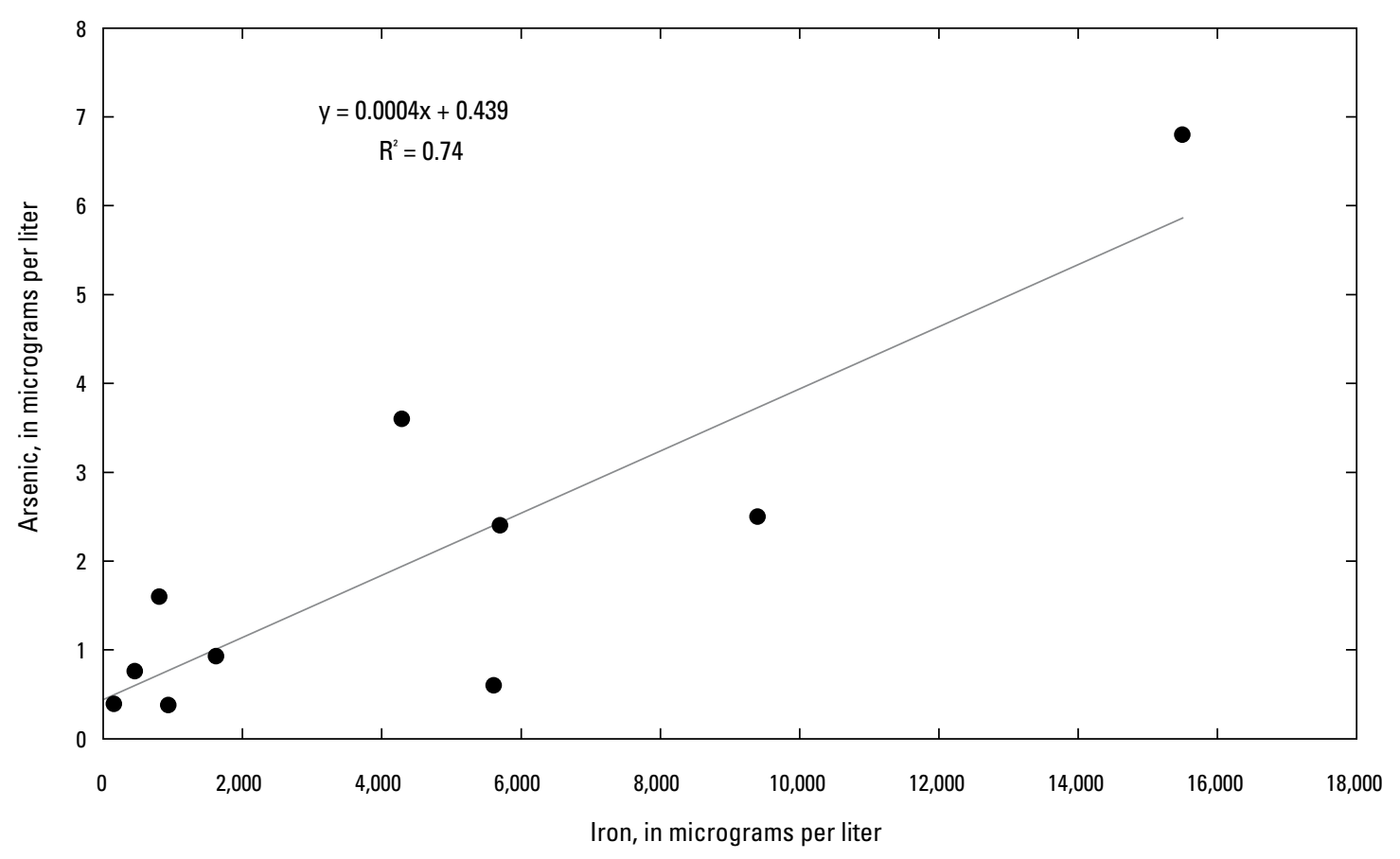

Figure 6. Arsenic and iron concentrations in groundwater samples from wells located in the Van Buren study area, Arkansas.

concentration of $0.02 \mu \mathrm{g} / \mathrm{L}$ at one site that was planted in beans at the time of sampling. Bentazon was the most frequently detected herbicide and was detected at three sites, although bentazon had not been used in recent years because of the widespread use of Roundup-Ready soybeans (Larry Martin, Yell County, Arkansas Cooperative Extension Service, oral commun., 2010). Kresse and Van Schaik (1996) noted decreasing, but persistent, bentazon concentrations in groundwater samples from a site in eastern Arkansas, although more than 10-12 years had passed following the last use of bentazon at this site. Kresse and others (1997) noted that bentazon was the most frequently detected pesticide in southeastern Arkansas in 14 of the 24 (58 percent) well-water samples with pesticide detections and had the highest solubility of all pesticides used in Arkansas. The high solubility and long-term persistence in groundwater possibly accounts for the detection of bentazon in the study area.

All but one of the pesticides detected in this study have water-solubility values exceeding $500 \mathrm{mg} / \mathrm{L}$ (Extension Toxicology Network, 1998), which account for their high mobility and high potential for migration to the groundwater table. The U.S. Environmental Protection Agency (1986) lists all pesticides with water solubility exceeding $30 \mathrm{mg} / \mathrm{L}$ as having a high leaching potential. Although atrazine has a slightly lower water solubility of $28 \mathrm{mg} / \mathrm{L}$, it is highly persistent in soil, does not adsorb strongly to soil (organic carbon partition coefficient $[\mathrm{Koc}]$ is 160 milliliters per gram $[\mathrm{mL} / \mathrm{g}]$ ), and has a lengthy half-life (60 to greater than 100 days); therefore, it has a high potential for migration to the groundwater table despite its lower solubility (Wauchope and others, 1992; Extension Toxicology Network, 2012). These results correspond closely to findings from Kresse and others (1997) and Kresse and Fazio (2002), who noted that the most frequently detected pesticides in the Mississippi River Valley alluvial aquifer had solubility values exceeding $500 \mathrm{mg} / \mathrm{L}$.

Despite the relatively high mobility and increased potential for migration to the water table, all pesticides were found in trace concentrations. Five of the six parent compounds detected in the samples were at estimated concentrations between the lower reporting limit and the method detection level for these compounds. Detected compounds were compared to the primary drinking-water standards and health advisories (U.S. Environmental Protection Agency, 2009), and all detections ranged from three to five orders of magnitude lower than the listed thresholds for health effects. Kresse and Fazio (2002) similarly noted that pesticide concentrations in samples from the Mississippi River Valley alluvial aquifer were three to five orders of magnitude below listed Federal drinking-water standards and published health advisories. In summary, the water quality of the groundwater in the Arkansas River Valley alluvial aquifer in the study area appears suitable for consumption and other uses; however, iron and manganese concentrations could be problematic based on intended uses. 


\section{Discussion of River Water and Groundwater Interaction}

One of the activities associated with this study was to assess the sources of recharge to the Arkansas River Valley alluvial aquifer in the study area, which is important for evaluating sustainable yields required for long-term, publicsupply water. The two major potential recharge sources for the Arkansas River Valley alluvial aquifer include (1) infiltration of precipitation through overlying alluvium and (2) leakage from the Arkansas River. The comparison of hydrographs to precipitation and river stage (see section "Hydrologic Characteristics") suggested that influx of water from the Arkansas River was minimal within the study area. Groundwater geochemistry provides another important and independent method for assessing influx of water from the Arkansas River into the Arkansas River Valley alluvial aquifer in the study area.

Chloride is a conservative, nonreactive ion that serves as a quantitative tracer for identifying various recharge sources, especially for sources having substantially different chloride concentrations. Chloride concentrations in the Arkansas River are substantially greater than chloride concentrations in the Arkansas River Valley alluvial aquifer derived as recharging precipitation undergoes evaporation and transpiration processes. Chloride concentrations measured at 10 sites on the Arkansas River from 1975 through 1985 revealed annual maximum chloride concentrations ranging from 220 to $550 \mathrm{mg} / \mathrm{L}$, with mean concentrations ranging from 90 to $115 \mathrm{mg} / \mathrm{L}$ (Petersen, 1988). The sites were located at various lock and dam systems along the river from near Fort Smith to near the confluence of the Mississippi River (fig. 1) - two of the sites were near the Trimble Lock and Dam in the study area. Kresse and Clark (2008) proposed that natural enrichment of chloride by evapotranspiration processes acting on infiltrating precipitation results in chloride concentrations less than $25 \mathrm{mg} / \mathrm{L}$ in the Mississippi River Valley alluvial aquifer near the Arkansas River in southeastern Arkansas. This finding assumes the absence of additional sources of salinity, such as mixing with higher salinity river water or upward migration of higher salinity groundwater from underlying formations. In spite of extensive use of groundwater from the Mississippi River Valley alluvial aquifer for irrigation, Kresse and Clark (2008) noted that chloride concentrations were consistently lowest in wells closest to the river from Little Rock, Ark., to the Mississippi River and proposed that the main source of recharge was infiltration of precipitation through proximal, coarse channel deposits along the river, rather than influx of water from the Arkansas River.

Where mixing of high-chloride water from a river with alluvial groundwater does occur, chloride concentration gradients should reflect this mixing by the appearance of high-chloride groundwater near the river transitioning to low-chloride groundwater further removed from the river, where other recharge sources dominate the groundwater geochemistry
(Adhikary and others, 2012). By way of example, if mean chloride concentration in a river was $300 \mathrm{mg} / \mathrm{L}$ and mean precipitation-derived groundwater concentration was $10 \mathrm{mg} / \mathrm{L}$, then a mixture of 20 percent river water and 80 percent precipitation-derived groundwater would have a concentration of $68 \mathrm{mg} / \mathrm{L}$; further away from the river, chloride concentrations would diminish to values approaching $10 \mathrm{mg} / \mathrm{L}$. A previous study (Kresse and others, 2006) applied similar techniques to identify a location where river water was infiltrating into the Arkansas River Valley alluvial aquifer. Kresse and others (2006) showed that intensive and continuous pumping from 12 municipal wells (3 well fields located approximately $0.5 \mathrm{mi}$ from one another) in the Arkansas River Valley alluvial aquifer in Dardanelle resulted in as much as 20 percent mixing of river water in the 1 production well nearest the river (0.4 mi) within 1 well field, with substantially less mixing in other wells in the same well field further removed from the river $(0.5-1.0 \mathrm{mi})$. One well located in a nearby well field that was only $1,200 \mathrm{ft}$ from the river had less than 5 percent mixing, demonstrating that the hydraulic connection between the river and the aquifer was not uniform along the stretch of river running parallel to the three well fields in the Dardanelle area. Although findings from Kresse and Clark (2008) suggest that precipitation recharging the aquifer through coarsegrained, permeable sediments proximal to the river is the dominant source of recharge along the Arkansas River Valley alluvial aquifer, infiltration of river water into the alluvial aquifer is more likely to occur where the aquifer and the river are hydraulically well connected and influx of river water is induced by continual pumping near to the river.

Chloride concentrations collected for this study were used as an additional analysis tool to evaluate influx of water from the Arkansas River into the Arkansas River Valley alluvial aquifer. Chloride concentrations in groundwater from wells sampled for this study ranged from 6.1 to $22 \mathrm{mg} / \mathrm{L}$ with a median concentration of $17 \mathrm{mg} / \mathrm{L}$, within a range of concentrations resulting from natural enrichment by evapotranspiration processes (Kresse and Clark, 2008). Chloride concentrations in samples from wells in the study area upstream from the dam were compared for predam and postdam sampling periods. The mean chloride concentration was $14 \mathrm{mg} / \mathrm{L}$ for groundwater samples from 24 wells sampled upstream from the dam between 1950 and 1959, which compares closely to the mean concentration of $15 \mathrm{mg} / \mathrm{L}$ for 5 wells sampled upstream from the dam for this study.

One possible exception to the absence of geochemical evidence for limited influx of water from the Arkansas River upstream from the dam is in the area of well C (figs. 1 and $5 B$ ). Whereas most chloride concentrations were less than or equal to $15 \mathrm{mg} / \mathrm{L}$ for wells closest to the river, chloride concentrations in three historical wells including well $\mathrm{C}$, a well $200 \mathrm{ft}$ east of well C, and a well $320 \mathrm{ft}$ northeast of well $\mathrm{C}$ were 24,31 , and $44 \mathrm{mg} / \mathrm{L}$, respectively. Although waterquality sampling occurred prior to dam installation, if influx of higher salinity river water resulted in the slightly elevated chloride concentrations, then this area indicates a location 
where the aquifer and river may be hydrologically connected to a larger degree than other locations in the study area. Presently, insufficient evidence is available to state with any certainly the source of the relatively elevated chloride concentrations and the possibility of a greater degree of surface-water/ groundwater interaction in the vicinity of well C.

Overall, the geochemical data support the interpretations from analysis of the hydrologic data, which showed welldefined responses to precipitation events with minimal effects by rising pool levels in the Arkansas River following dam construction. These combined hydrologic and geochemical data suggest that the dominant source of recharge is infiltration of precipitation through coarse channel deposits with minimal influx of water from the Arkansas River. The possibility of bank storage effects and temporary fluctuations in groundwater levels caused by influx of river water near to the river cannot be discounted, but any appreciable recharge from the river into the main body of alluvium is not supported by hydrologic or geochemical data.

\section{Implications of Study Results}

One purpose of this study was to evaluate the Arkansas River Valley alluvial aquifer as a viable source of publicsupply water for Van Buren, Ark., and surrounding communities. Lithologic data show thicknesses of sand (and minor gravel) near the base of the alluvial sediments serving as the dominant production zone are comparable to similar production-zone (basal sand and gravel) thicknesses in the Dardanelle area, which uses the Arkansas River Valley alluvial aquifer as a sole source of public-supply water-Dardanelle used greater than $2.5 \mathrm{Mgal} / \mathrm{d}$ of water from the Arkansas River Valley alluvial aquifer in 2013. Anecdotal evidence from farmers in the study area, supported by the identification of low sand-percent deposits, indicates that large parts of the aquifer in the study area may not provide well yields necessary for most uses, especially for that of public-supply water.

Hydrographs created from historical water-level data allowed comparisons of changing water levels to precipitation and river stage. These hydrologic data indicated minimal discernible influx of water from the Arkansas River prior to and after dam installation and suggest that infiltration of precipitation through overlying alluvium (the more permeable sediments associated with channel and natural-levee deposits having the highest potential recharge) is the dominant source of recharge in the study area. This finding is supported by past studies in the Dardanelle area (Kresse and others, 2006) and in southeastern Arkansas (Kresse and Clark, 2008). A comparison of chloride concentrations in the Arkansas River to chloride concentrations in the Arkansas River Valley alluvial aquifer in the study area also supports the interpretation of minimal recharge from the Arkansas River.

The data gathered for this study provide a preliminary, qualitative assessment of the potential of the Arkansas River Valley alluvial aquifer as a source of public-supply water.
Hydrologic data and review of yields from irrigation wells in the study area indicate that if vertical supply wells are installed (actual number of wells depends on projected water requirements), then several wells will have to be used, pumped at relatively low individual rates (approximately $200 \mathrm{gal} / \mathrm{min}$ based on data for the city of Dardanelle), and placed in areas of higher sand content for optimum yields. Until 2011, Dardanelle depended on 12 production wells pumping at individual rates of approximately $200 \mathrm{gal} / \mathrm{min}$ to supply as much as $820 \mathrm{Mgal} / \mathrm{yr}$ of groundwater from the Arkansas River Valley alluvial aquifer for public-supply water (Bill Smith, Dardanelle Water Works, written commun., 2010). Similar pumping rates may be obtainable within the study area but would require a more detailed hydrologic assessment including obtaining multiple soil cores, drilling test wells, and performing aquifer tests. As of 2011, Dardanelle was pumping as much as $2.5 \mathrm{Mgal} / \mathrm{d}$ (estimated maximum yield of 3.0 Mgal/d) from a horizontal collector well comprising six laterals with a total of $1,180 \mathrm{ft}$ of lateral screen in a semicircular configuration (Brechtel Radial Collector Wells, 2010); two of the lateral screened sections were parallel to and within approximately $300 \mathrm{ft}$ of the river. Proposed subsequent studies have not been conducted to determine the amount of induced river-water recharge following installation of the new collector system in Dardanelle; however, it is likely that a greater proportion of river water is now being induced based on data from Kresse and others (2006). The success of a comparable configuration for the study area may depend greatly on influx of river water to supplement water recharging from infiltration of precipitation, thus effectively replacing the amount of water removed from groundwater storage. This supplementary river water would reduce groundwater-level declines associated with pumping at rates greater than precipitation-recharge rates, especially where zones of lower permeability sediments overlie the aquifer. If a reduced hydraulic connection (for example, fine sediment in the riverbed that reduces hydraulic conductivity and impedes influx of water from the river) exists between the river and the alluvium, then production will depend on ample precipitation and surface-derived recharge throughout the year and sufficient storage in a continuous and permeable (sand and gravel) production zone to meet production demands.

The relative contributions of recharge derived from precipitation and river leakage have implications for protection of groundwater quality and quantity for use as a publicsupply water. Depending on well-system configuration (areally distributed vertical wells or horizontal well collector system), various scenarios might need to be considered for protecting groundwater quality and ensuring sustainable water quantity. Although results from this study indicate that infiltration of precipitation through overlying alluvium is the predominant source of recharge, induced infiltration of river water by continuous pumping of groundwater for municipal supply would increase vulnerability to the aquifer from potential spills, runoff, or other releases of potential contaminants into the river, which could be transported with river water into 
the well field. If influx of river water is a minor component of the recharge to the aquifer following aquifer development as a public-supply water, then protection of the recharge area becomes a potential concern. Although not meant to be an inclusive list of all management scenarios, several considerations where areal distributed recharge of infiltrating precipitation is the predominant source of recharge might include: (1) a proactive approach for protecting water quality from potential contaminants derived from various land uses - presently rowcrop agriculture is the dominant land use, with use of fertilizers and pesticides being a main concern; (2) managing the land to maximize recharge - land use and land cover affects optimum recharge, and conversion of forest or other natural settings to urban or other land uses can affect runoff/recharge ratios in the area of concern, thus affecting recharge rates; (3) flood-control measures are common in low-lying areas but can have unanticipated negative effects by preventing inundation of water acting to extend time of infiltration, increase the hydraulic drive for infiltration, and minimizing evaporation and transpiration; and (4) excessive lowering of water levels from overpumping (where pumping for municipal supply exceeds the rate of recharge), especially during dry periods and drought years when recharge is at a minimum, can result in compaction of the aquifer matrix, resulting in decreased storage and hydraulic conductivity that can damage the aquifer and resulting well yields. Additionally, irrigation use, while minimal in the study area, contributes to overall use of the Arkansas River Valley alluvial aquifer in the study area.

\section{Summary}

A study to assess the potential of the Arkansas River Valley alluvial aquifer in the vicinity of Van Buren, Arkansas, as a viable source of public-supply water was conducted by the U.S. Geological Survey in cooperation with the Little Rock District, U.S. Army Corps of Engineers. The study described the lithology, hydrologic characteristics, and water quality of groundwater from the Arkansas River Valley alluvial aquifer near Van Buren, Ark., and assessed dominant sources of recharge prior to and after the installation of James W. Trimble Lock and Dam 13 (December 1969) on the Arkansas River. Drillers' logs from 59 observation wells drilled from 1957 through 1959 in the study area were available to characterize sediment type and thickness of the lower producing sand. Water-quality samples were collected from 10 irrigation wells. In order to evaluate the potential viability of the Arkansas River Valley alluvial aquifer in the Van Buren area, these data were compared to similar stratigraphic, lithologic, and groundwater-quality data from the Arkansas River Valley alluvial aquifer near Dardanelle, Ark., which is a proven, productive aquifer and sole-source public-supply water.

The Arkansas River Valley alluvial deposits are a coarsening downward sequence comprising silts and clays at the surface and sands and gravels near the base. Logs of observation wells drilled from 1957 through 1959 were used to assess local stratigraphy within the study area and for comparison to drillers' logs of wells installed for public-supply water in Dardanelle, Ark. In the study area, the presence of gravel was noted in only 4 of $59 \operatorname{logs}$, and the total depth of the 59 wells ranged from 25 to 52 feet (ft), with a mean depth of $42 \mathrm{ft}$. The thickness of the lower sand/gravel interval serving as the production zone ranged from 5 to $47 \mathrm{ft}$, with a mean thickness of $29 \mathrm{ft}$. In the Dardanelle area, gravel was noted near the basal section in 11 of 12 wells for which logs were available; the thickness of the production zone ranged from 8 to $69 \mathrm{ft}$ with a mean thickness of $21 \mathrm{ft}$.

The percent sand representing the production zone was calculated using sand thickness divided by well depth from available drillers' logs in the study area, and these sand percentages were overlain onto an orthophotograph map to examine the areal distribution of sand percentage in relation to geomorphologic features. The wells with the greatest percent sand were in areas near to the river and on the concave (point bar) side of each of the abandoned channels, and the wells with lower percent sand were on the convex (channel fill, backswamp) side of the stream segment. The distribution of these deposits of varying permeability appears to support anecdotal information in regard to the distribution of productive wells in the area and the occurrence and close proximity of less permeable boundaries encountered by expanding cones of depression during irrigation well pumping in the study area.

Comparison of well hydrographs to cumulative departure from mean monthly and mean annual precipitation showed overall good fit and explained the long-term decreasing water levels from the earliest period of record to October 1967, followed by a sharp rise in water levels concurrent with rises in cumulative departure from mean monthly and annual precipitation. Hydrographs for four wells upstream from the dam and ranging from 0.8 to $4.5 \mathrm{mi}$ from the river that were potentially affected by rising pool levels also were assessed in regard to river stage and cumulative departure from mean monthly precipitation. Water levels for these wells generally showed minimal discernible effects of rising river stage following dam completion. Periods of increased precipitation compare closely to increases in water level for all hydrographs, regardless of river stage, and water levels additionally declined during periods of no precipitation, although river stage continued to slowly rise following dam completion.

Ten wells in the study area were sampled to determine water quality, water type, and geochemistry of the Arkansas River Valley alluvial aquifer. Groundwater in the study area is a calcium-bicarbonate water type. No primary drinkingwater standards were exceeded, and iron and manganese were the only constituents that exceeded the secondary drinkingwater regulations. The secondary drinking-water regulations are unenforceable Federal guidelines regarding taste, odor, color, and other aesthetic effects of drinking water that are not related to human health concerns.

Six of the 10 groundwater samples were analyzed for pesticides because of the dominant agricultural land use in the study area. Six herbicide compounds and one herbicide 
metabolite were detected; five of the six wells had at least one herbicide detection. The compounds detected in the samples include tebuthiuron, triclopyr, metolachlor, imazaquin, bentazon, atrazine, and 2-chloro-4-isopropylamino-6-amino-striazine (deethylated metabolite of atrazine). Detected compounds were compared to the primary drinking-water standards and health advisories, and all detections ranged from three to five orders of magnitude lower than the listed thresholds for health effects.

Hydrologic and geochemical data were used to assess the dominant source of recharge to the Arkansas River Valley alluvial aquifer. The hydrologic data indicated minimal influx of river water into the aquifer in the study area. Chloride concentration used as a conservative tracer for infiltration of river water was consistent with hydrologic data; these data suggest that the dominant source of recharge is vertical infiltration of precipitation through coarse-channel and natural-levee deposits. Examination of chloride concentrations in the Arkansas River from 1975 through 1985 revealed annual maximum chloride concentrations ranging from 220 to $550 \mathrm{mg} / \mathrm{L}$, with monthly mean concentrations ranging from 90 to $150 \mathrm{mg} / \mathrm{L}$. The mean chloride concentration for groundwater from 24 wells in the study area upstream from the dam and sampled between 1950 and 1959 (predam) was $14 \mathrm{mg} / \mathrm{L}$, compared to a mean concentration of $15 \mathrm{mg} / \mathrm{L}$ for groundwater from 5 wells sampled for this study in 2010 (postdam) upstream from the dam.

The data gathered for this study provide a preliminary, qualitative assessment of the potential of the Arkansas River Valley alluvial aquifer for use as a source of public-supply water. If vertical wells are to be used as a viable water supply, several wells will have to be used in combination at relatively low pumping rates and placed in areas of higher sand content. Use of a horizontal well collector configuration near the river to increase production may depend on infiltration of river water to supplement water recharged by infiltrating precipitation and that removed from groundwater storage, especially where zones of lower permeability sediments might be encountered within the surrounding alluvium. If a reduced hydraulic connection exists between the river and the aquifer, as is indicated by this study, then production will depend on ample precipitation and surface recharge throughout the year and groundwater storage sufficient to prevent declining water levels where pumping rates exceed recharge.

\section{References Cited}

Adhikary, K.S., Gupta, A.D., Babel, M.S., Perret, S.R., and Clemente, R.S., 2012, Simulating river-aquifer dynamic interaction in the regional unconfined aquifer of southwestern Bangladesh: Journal of Engineering Science, v. 3, no. 1, p. $147-160$.

Ackerman, D.J., 1996, Hydrology of the Mississippi River Valley alluvial aquifer, South-Central United States: U.S. Geological Survey Professional Paper 1416-D, 56 p.
Arthur, J.K., 2001, Hydrogeology, model description, and flow analysis of the Mississippi River alluvial aquifer in northwestern Mississippi: U.S. Geological Survey WaterResources Investigations Report, 2001-4035, 47 p.

Barlow, P.M., and Leake, S.A., 2012, Streamflow depletion by wells-Understanding and managing the effects of groundwater pumping on streamflow: U.S. Geological Survey Circular 1376, 84 p.

Bedinger, M.S., Emmett, L.F., and Jeffery, H.G., 1963, Ground-water potential of the alluvium of the Arkansas River between Little Rock and Fort Smith, Arkansas: U.S. Geological Survey, Water Supply Paper, 1669-L, 29 p.

Bedinger, M.S., and Jeffery, H.G., 1964, Ground water in the Lower Arkansas River Valley, Arkansas: U.S. Geological Survey Water-Supply Paper 1669-V, 17 p.

Bedinger, M.S., and Reed, J.E., 1961, Geology and groundwater resources of Desha and Lincoln Counties, Arkansas: Arkansas Geology and Conservation Commission Water Resources Circular 6, 129 p.

Brechtel Radial Collector Wells, LLC, 2010, Performance testing results - horizontal collector well, Dardanelle, Arkansas: Report prepared for the City of Dardanelle, Arkansas, $19 \mathrm{p}$.

Childress, C.J.O., Forman, W.T., Connor, B.F., and Maloney, T.J., 1999, New reporting procedures based on long-term method detection levels and some considerations for interpretations of water- quality data provided by the U.S. Geological Survey National Water Quality Laboratory: U.S. Geological Survey Open-File Report 99-193, 19 p.

Cordova, R.M., 1964, Reconnaissance of the ground-water resources of the Arkansas Valley region: U.S. Geological Survey Water Supply Paper 1669-BB, 33 p.

Extension TOXicology NETwork (EXTOXNET), 2012, Pesticide information profiles (PIPs): Collaborative project of University of California, Davis, Oregon State University, Michigan State University, Cornell University, and the University of Idaho, accessed July 2010, at http://extoxnet. orst.edu/.

Fishman, M.J., 1993, Methods of analysis by the U.S. Geological Survey National Water Quality Laboratory-Determination of inorganic and organic constituents in water and fluvial sediments: U.S. Geological Survey Open-File Report 93-125, $217 \mathrm{p}$.

Freeman, L.A., Carpenter, M.C., Rosenberry, D.O., Rousseau, J.P., Unger, R., and McLean, J.S., 2004, Use of submersible pressure transducers in water-resources investigations: U.S. Geological Survey Techniques of Water-Resources Investigations, book 8, chap. A, 65 p. 
Furlong, E.T., Anderson, B.D., Werner, S.L., Soliven, P.P., Coffey, L.J., and Burkhardt, M.R., 2001, Methods of analysis by the U.S. Geological Survey National Water Quality Laboratory-Determination of pesticides in water by graphitized carbon-based solid-phase extraction and high-performance liquid chromatography/mass spectrometry: U.S. Geological Survey Water-Resources Investigations Report 01-4134, $73 \mathrm{p}$.

Garbarino, J.R., 1999, Methods of analysis by the U.S. Geological Survey National Water Quality Laboratory-Determination of dissolved arsenic, boron, lithium, selenium, strontium, thallium, and vanadium using inductively coupled plasma-mass spectrometry: U.S. Geological Survey OpenFile Report 99-093, 31 p.

Holland, T.E., 2007, Water use in Arkansas, 2005: U.S. Geological Survey Scientific Investigations Report 2007-5241, $32 \mathrm{p}$.

Klein, Howard, Baker, R.C., and Billingsley, G.A., 1950, Ground-water resources of Jefferson County, Arkansas: Arkansas University, Institute of Science and Technology Research Series 19, 44 p.

Kline, S.W., Kresse, T.M., Fazio, J.A., Prior, W.L., Hanson, W.D., Miller, R.A., Treece, T.M., 2006, The Arkansas River's alluvial aquifer in central Arkansas-Physical hydrology of the aquifer at Dardanelle [abs.]: Fayetteville, Ark, Proceedings of the Arkansas Water Resources Center Annual Conference, April 18-19, 2006, 1 p.

Kresch, D.L., 1994, Variability of streamflow and precipitation in Washington: U.S. Geological Survey Water-Resources Investigations Report 93-4132, 32 p.

Kresse, T.M., and Clark, B.R., 2008, Occurrence, distribution, sources, and trends of elevated chloride concentrations in the Mississippi River Valley alluvial aquifer in southeastern Arkansas: U.S. Geological Survey Scientific Investigations Report 2008-5193, 34 p.

Kresse, T.M., and Fazio, J.A., 2002, Pesticides, water quality, and geochemical evolution of ground water in the alluvial aquifer, Bayou Bartholomew Basin, Arkansas: Arkansas Department of Environmental Quality, Water Quality Report WQ02-05-1, $111 \mathrm{p}$.

Kresse, T.M., and Fazio, J.A., 2003, Occurrence of arsenic in ground waters of Arkansas and implications for source and release mechanisms: Arkansas Department of Pollution Control and Ecology, Water Quality Report WQ03-03-01, 35 p.

Kresse, T.M., Fazio, J.A., Miller, R.A., and Kline, S.W., 2006, The Arkansas River's alluvial aquifer in central Arkansas - Geochemistry of the aquifer at Dardanelle [abs.]: Fayetteville, Ark., Proceedings of the Arkansas Water Resources Center Annual Conference, April 18-19, 2006, 1 p.
Kresse, T.M., and Van Schaik, E.J., 1996, Preliminary results of pesticide investigation, Augusta, Arkansas: Arkansas Department of Pollution Control and Ecology, Special Investigation Report SI96-11-1, 17 p.

Kresse, T.M., Van Schaik, E.J., Wise, James, and Huetter, T.A., 1997, Occurrence of pesticides in alluvial aquifer of eastern Arkansas: Arkansas Department of Pollution Control and Ecology, Water Quality Report WQ97-10-1, 39 p.

Mahon, G.L., and Ludwig, A.H., 1990, Simulation of groundwater flow in the Mississippi River Valley alluvial aquifer in eastern Arkansas: U.S. Geological Survey Water-Resources Investigations Report 89-4145, 26 p.

Mahon, G.L., and Poynter, D.T., 1993, Development, calibration, and testing of ground-water flow models for the Mississippi River Valley alluvial aquifer in eastern Arkansas using one-square-mile cells: U.S. Geological Survey Water-Resources Investigations Report 92-4106, 33 p., 11 pls.

McKee, P.W., and Clark, B.R., 2003, Development and calibration of a ground-water flow model for the Sparta aquifer of southeastern Arkansas and north-central Louisiana and simulated response to withdrawals, 1998-2027: U.S. Geological Survey Water-Resources Investigations Report 03-4132, $68 \mathrm{p}$.

National Oceanic and Atmospheric Administration, 2010, National Climatic Data Center: Accessed September 24, 2010, at http://www.ncdc.noaa.gov.

Petersen, J.C., 1988, Statistical summary of selected waterquality data (water years 1975 through 1985) for Arkansas rivers and streams: U.S. Geological Survey WaterResources Investigations Report 88-4112, 189 p.

Prior, W.L., Howard, J.M., McFarland, J.D., and Hill, S.S., 1999, Roubidoux Formation and Gunter Sandstone Member of the Gasconade Formation, major aquifers in northern Arkansas: Arkansas Geological Commission Water Resources Circular no. 17, 45 p.

Pugh, A.L., and Westerman, D.A., 2014, Mean annual, seasonal, and monthly precipitation and runoff in Arkansas, 1951-2011: U.S. Geological Survey Scientific Investigations Report 2014-5006, 40 p., accessed [July 2010], at http://pubs.er.usgs.gov/publication/sir20145006.

Radtke, D.B., Davis, J.V., and Wilde, F.D., 2005, Specific electrical conductance (ver. 1.2): U.S. Geological Survey Techniques of Water-Resources Investigations, book 9, chap. A6., sec. 6.3, accessed [July 2010], at http://pubs. water.usgs.gov/twri9A6/. 
Reed, T.B., 2003, Recalibration of a ground-water flow model of the Mississippi River Valley alluvial aquifer of northeastern Arkansas, 1918-1998, with simulations of water levels caused by projected ground-water withdrawals through 2049: U.S. Geological Survey Water-Resources Investigations Report 03-4109, 58 p.

Ritz, G.F., and Collins, J.A., 2008, pH (ver. 2.0): U.S. Geological Survey Techniques of Water-Resources Investigations, book 9, chap. A6., sec. 6.4, accessed [July 2010], at http://pubs.water.usgs.gov/twri9A6/.

Sandstrom, M.W., Wydoski, D.S., Schroeder, M.P., Zamboni, J.L., and Foreman, W.T., 1992, Methods of analysis by the U.S. Geological Survey National Water Quality Laboratory-Determination of organonitrogen herbicides in water by solid-phase extraction and capillary-column gas chromatography/mass spectrometry with selected-ion monitoring: U.S. Geological Survey Open-File Report 91-519, 26 p.

Sharif, M.U., Davis, R.K., Steele, K.F., Kim, B., Hays, P.D., Kresse, T.M., and Fazio, J.A., 2008a, Distribution and variability of redox zones controlling spatial variability of arsenic in the Mississippi River Valley alluvial aquifer, southeastern Arkansas: Journal of Contaminant Hydrology, v. 99, p. 49-67.

Sharif, M.U., Davis, R.K., Steele, K.F., Kim, B., Kresse, T.M., and Fazio, J.A., 2008b, Inverse geochemical modeling of groundwater evolution with emphasis on arsenic in the Mississippi River Valley alluvial aquifer, Arkansas (USA): Journal of Hydrology, v. 350, p. 41-55.

Stanton, G.P., and Clark, B.R., 2003, Recalibration of a ground-water flow model of the Mississippi River Valley alluvial aquifer in southeastern Arkansas, 1918-1998, with simulations of hydraulic heads caused by projected groundwater withdrawals through 2049: U.S. Geological Survey Water-Resources Investigations Report 03-4232, 48 p.
Stogner, W.R., Sr., 2000, Trends in precipitation and streamflow and changes in stream morphology in the Fountain Creek watershed, Colorado, 1939-99: U.S. Geological Survey Water-Resources Investigations Report 00-4130, $43 \mathrm{p}$.

U.S. Environmental Protection Agency, 1986, Pesticides in ground water-Background document: Washington, D.C., Office of Ground Water Protection, WH-550G, 72 p.

U.S. Environmental Protection Agency, 2009, 2009 edition of the drinking water standards and health advisories: Washington, D.C., Office of Water, EPA 822-R-09-011, 12 p.

U.S. Geological Survey, 2010, USGS water data for the Nation: U.S. Geological Survey National Water Information System (NWISWeb), accessed August 23, 2010, at http://waterdata.usgs.gov/nwis.

Wauchope, R.D., Buttler, T.M., Hornsby, A.G., AugustijnBeckers, P.W.M., and Burt, J.P., 1992, The SCS/ARS/CES pesticide properties database for environmental decisionmaking: Reviews of Environmental Contamination and Toxicology, v. 123, p. 1-156.

Weber, K. and Stewart, M., 2004, A critical analysis of the cumulative rainfall departure concept: Ground Water, v. 42, no. 6, p. 935-938.

Wilde, F.D., ed., 2004, Cleaning of equipment for water sampling (ver. 2.0): U.S. Geological Survey Techniques of Water-Resources Investigations, book 9, chap. A3, accessed [July 7, 2010], at http://pubs.water.usgs.gov/twri9A3/.

Wilde, F.D., 2006, Temperature (ver. 2): U.S. Geological Survey Techniques of Water-Resources Investigations, book 9, chap. A6., sec. 6.1, accessed [July 2010], at http://pubs. water.usgs.gov/twri9A6/. 
